\title{
Subsoil constraints to grain production in the cropping soils of the north-eastern region of Australia: an overview
}

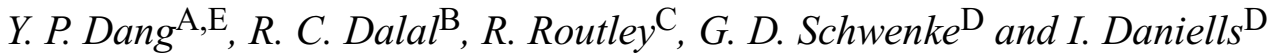

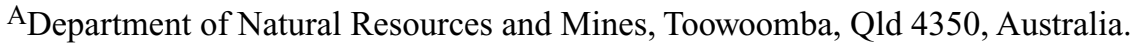 \\ BDepartment of Natural Resources and Mines, Indooroopilly, Qld 4068, Australia. \\ ${ }^{C}$ Department of Primary Industries and Fisheries, Emerald, Qld 4720, Australia. \\ DNSW Department of Primary Industries, Tamworth Agricultural Institute, \\ 4 Marsden Park Road, Calala, NSW 2340, Australia. \\ ${ }^{\mathrm{E}}$ Corresponding author. Email: yash.dang@nrm.qld.gov.au
}

\begin{abstract}
In dryland agricultural systems of the subtropical, semi-arid region of north-eastern Australia, water is the most limiting resource. Crop productivity depends on the efficient use of rainfall and available water stored in the soil during fallow. Agronomic management practices including a period of fallow, stubble retention, and reduced tillage enhance reserves of soil water. However, access to stored water in these soils may be restricted by the presence of growth-limiting conditions in the rooting zone of the crop. These have been termed as subsoil constraints. Subsoil constraints may include compacted or gravel layers (physical), sodicity, salinity, acidity, nutrient deficiencies, presence of toxic elements (chemical) and low microbial activity (biological). Several of these constraints may occur together in some soils.

Farmers have often not been able to obtain the potential yield determined by their prevailing climatic conditions in the marginal rainfall areas of the northern grains region. In the past, the adoption of soil management practices had been largely restricted to the top $100 \mathrm{~mm}$ soil layer. Exploitation of the subsoil as a source of water and nutrients has largely been overlooked. The key towards realising potential yields would be to gain better understanding of subsoils and their limitations, then develop options to manage them practically and economically. Due to the complex nature of the causal factors of these constraints, efforts are required for a combination of management approaches rather than individual options, with the aim to combat these constraints for sustainable crop production, managing natural resources and avoiding environmental damage.
\end{abstract}

\section{Introduction}

Major cropping areas of the north-eastern region of Australia include central Queensland, southern Queensland and northern New South Wales (NSW). Vertosols make up a major proportion of both irrigated and dryland cropped soils in these regions. Although these soils are often regarded as well structured, crop production in the region appears to be restricted owing to slowly permeable subsoils and shallow rooting depths associated with subsoil constraints (Dalal et al. 2002; Irvine and Doughton 2001). These subsoil constraints include sodicity and salinity in the cracking soils of northwest NSW (Daniells et al. 2002) and southern Queensland (Dalal et al. 2002), acidity in Brigalow soils (Ahern et al. 1993), and sodicity in Vertosols of central Queensland (Irvine and Doughton 2001). Many subsoils also have toxic concentrations of carbonate $\left(\mathrm{CO}_{3}{ }^{2-}\right)$, bicarbonate $\left(\mathrm{HCO}_{3}{ }^{-}\right)$, chloride $\left(\mathrm{Cl}^{-}\right)$and aluminium $\left(\mathrm{Al}^{3+}\right)$, as well as compaction (Ahern et al. 1993; McGarry 1992; Shaw et al. 1994).

For dryland crop production, soils need to store at least 120 $\mathrm{mm}$ of plant-available water in most seasons during the fallow period (Muller 1999). Many soils of the region are able to store
200-250 mm water in the soil profile (Dalgliesh and Foale 1998; Daniells et al. 2002). However, the presence of and depth of sodicity, salinity or acidity, alone or in combination, in soil can reduce the effective rooting depth of plants and hence, the amount of water that plants can access from the soil (Dalal et al. 2002; Dalgliesh and Biggs 2003; Shaw 1997).

Recent studies have identified significant chemical subsoil constraints including subsoil sodicity and subsoil salinity for cereal cropping (Dalal et al. 2002; Irvine and Doughton 2001) and possibly subsoil acidity in the brigalow soils (Ahern et al. 1993; Dalal et al. 1995). Further surveys of the northern region confirmed the widespread occurrence of these subsoil constraints (Dalal et al. 2002; Dang et al. 2004c; Irvine and Doughton 2001; Routley 2003; Schwenke 2002). In this present paper, we review the literature concerning the extent of subsoil constraints; the soil and landscape processes leading to these constraints; their impact on soil, plant, farming systems and environment; and management options in combating these constraints for sustainable production and environment in the north-eastern grains region of Australia (subsequently referred to as the northern region). 


\section{Characterisation of northern region}

The northern cropping region of Australia includes the subtropical cereal belt located within the Fitzroy and Murray-Darling basins of north Australia. It includes the Central Highlands and Dawson-Callide in central Queensland; the Darling Downs and Western Downs in southern Queensland; and the north-west slopes and plains of NSW (Webb et al. 1997).

The climate of the region varies from subtropical in the east to semi-arid in the west. Most areas of the region receive 600-800 mm median annual rainfall with rainfall distribution changing from summer dominant in central Queensland to a uniform winter-summer distribution in northern NSW. This rainfall distribution provides an opportunity to grow a range of crops in both summer and winter seasons (Webb et al. 1997).

The northern region is associated with a diverse range of grasslands, scrub, Eucalyptus open forest, and brigalow forest or woodlands. Large scale clearing of native vegetation, which commenced about 100 years ago, made way for crop production but also led to land and water degradation (SalCon 1997).

The distribution of soils in the region is related to geology, geomorphic processes and topography. The major cropping soils in the northern region with subsoil constraints include grey, brown and black Vertosols, and red, brown and black Sodosols (Webb et al. 1997).

\section{Soil and landscape processes leading to subsoil constraints in the northern region}

Subsoil sodicity

Sodicity results from the build up of sodium $\left(\mathrm{Na}^{+}\right)$ions in preference to calcium $\left(\mathrm{Ca}^{2+}\right)$ on the soil cation exchange complex. In the northern region, weathering of rock and sediment was the main source of salts in the development of soil sodicity, along with the use of groundwater containing mainly sodium bicarbonate (Cassidy 1971). Sodium accessions from rainfall and aeolian sources appear to have contributed little to sodicity in these soils (Shaw et al. 1994). The inherent sodicity of subsoil in these soils is the major factor determining their higher strength and lack of porosity. Use of wastes from intensive livestock industries may also contribute to soil sodicity and salinity (Sinclair et al. 1996).

\section{Subsoil salinity}

Subsoil salinity can be a significant limitation to crop production where high salt concentration occurs in the rootzone. Subsoil salinity in the northern region is different from dryland salinity relating to groundwater seepage or that induced by a shallow watertable (SalCon 1997), and transient salinity in southern Australia due to a perched watertable (Rengasamy 2002).

Evaporation from the soil surface leaves salts in soils and the landscape. Transpiration through vegetation concentrates salts in the root-zone. In the northern region, the evaporative demand is 3-5 times higher than precipitation; the soil dries from the top down resulting in little leaching of salts below the root-zone (Shaw 1997). Before agriculture was introduced, salts accumulated below the root-zone of native vegetation as little leaching occurred below this zone. Dalal (1986) showed that leaching of salts from surface soil and accumulation in the subsoils resulted from increased water available for leaching. The clay subsoil also hindered the movement of water and salt, resulting in a bulge of salt accumulating in the soil layers between 5 and $30 \mathrm{~m}$ soil depth from the surface with groundwater below 35-60 m (Leaney and Herczeg 1999).

\section{Subsoil acidity}

There is wealth of information on the processes of soil acidification (Helyar and Porter 1989); however, the causes of subsoil acidification are poorly understood. In general, soil acidification results from natural weathering processes and imbalances within the carbon $(\mathrm{C})$ and nitrogen $(\mathrm{N})$ cycles. Nitrogen transformation and nitrate $\left(\mathrm{NO}_{3}{ }^{-}\right)$leaching in the $\mathrm{N}$ cycle have been suggested to be major causes of soil acidity (Bolan et al. 1991). Brigalow (Acacia harpophylla), an $\mathrm{N}_{2}$-fixing tree species, tends to overlay acidic subsoils (Ahern et al. 1993). However, it is unclear whether these Ntransformation processes cause subsoil acidification, as the organisms involved in the N-cycle are either absent or inhibited by soil environmental conditions in the subsoil (Page et al. 2002).

Subsoil toxic ions $\left(\mathrm{Cl}^{-}, \mathrm{B}^{-}, \mathrm{CO}_{3}^{-}, \mathrm{HCO}_{3}^{-}\right)$

The main sources of $\mathrm{Cl}^{-}$accumulation in the landscape were through parent material and rainfall (SalCon 1997) whereas boron $\left(\mathrm{B}^{-}\right)$in the soils is derived from marine sediments and various anthropogenic sources including irrigation water from mining, fly ash and industrial chemicals (Nable et al. 1997). The accumulation of $\mathrm{CO}_{3}{ }^{2-}$ and $\mathrm{HCO}_{3}{ }^{-}$were derived from ground water, seawater and precipitates in soil (Shaw et al. 1994) and also linked to sequestration of C (Knowles and Singh 2003).

\section{Subsoil infertility}

The amount of available nutrients is generally lower in subsoils than topsoils because of nutrient cycling and fertilizer additions in the topsoil (Graham et al. 1992). Subsoil infertility reduces the rate of root growth, increases the susceptibility of roots to diseases and enhances the ability of the crops to tolerate abiotic stresses, as most of the root system will be restricted to the surface layers where fertilizers have been applied (Graham et al. 1992).

\section{Subsoil biota}

Most soil microbial activities have been found concentrated in the surface soil of the majority of agricultural soils in Australia (Gupta 2004) including Vertosols in the northern region (Bell 2004). The inability of the soils to sustain 
significant microbial activity in the subsoil is attributed to a low level of biologically available C (Gupta 2004). The decrease in potentially mineralisable $\mathrm{N}$ with soil depth has been observed in a Vertosol in southern Queensland (Hossain et al. 1996), which might have an impact on the reduced biological activity in the subsoil (Bell 2004; Gupta 2004).

\section{Subsoil compaction and inherently dense subsoil matrix}

Compaction in subsoil influences root distribution by reducing soil porosity and increasing soil strength. Subsoil compaction may be either anthropogenic or inherent. Clay soils in particular are susceptible to anthropogenic-induced compaction (from tillage or tyres). The high clay contents of these soils retain and hold water for long periods of time, keeping the soil wetter and above the plastic limit hence, making it susceptible to physical damage (McGarry 1992).

Inherently dense subsoils (with bulk density $>1.7 \mathrm{Mg} / \mathrm{m}^{3}$ ) may also occur naturally in the subsoil $(>0.5 \mathrm{~m})$. This is particularly the case with non-cracking soils, as well as grey Vertosols and red-brown clays of the region (Dalgliesh and Foale 1998). Most of these subsoils are inherently sodic and poorly permeable. The inherently dense subsoil with high bulk density might have been the result of the overlaying weight of the soil, clay mineralogy, and inappropriate proportions of soil particles with large fractions of silt and fine sand in the subsoil, filling the pore spaces and resulting in large values of bulk density (D. McGarry, pers. comm.).

\section{Impact of subsoil constraints on crops, farming and environment}

Subsoil constraints have a significant impact on soil, water and nutrient regime, gaseous exchange between soil and atmosphere, and crop growth. Adverse effects on crop growth result in agronomic and economic losses, whereas adverse effects on soil-water and aeration regimes may result in ecological and environmental problems (Lal 1995). A number of characteristics in the subsoil interact with each other to determine the edaphic environment in which plant roots live at a given time. Physical (structural decline and compaction of soil layers), chemical (nutrient deficiencies and toxicities, sodicity, salinity and acidity) and biological (low microbial and faunal activities or increased incidence of diseases) constraints in the subsoil prevent or hinder the development of root systems and ultimately impact on crop yield (Rengasamy et al. 2003).

The general effects of subsoil constraints on soil, plant growth, farming and environment are presented schematically in Figure 1. Specifically, physical subsoil constraints result in low porosity restricting the rate of water and nutrient uptake whereas high soil strength inhibits root elongation and expansion thereby reducing water availability for transpiration (Radford et al. 2000).

The presence of salts and toxic elements directly affects root functions and reduces microbial activity. A high proportion of $\mathrm{Na}^{+}$ions on the clay cation exchange complex (sodicity) in comparison with $\mathrm{Ca}^{2+}$, magnesium $\left(\mathrm{Mg}^{2+}\right)$ and potassium $\left(\mathrm{K}^{+}\right)$ions results in poor soil-water relations in many soils (So and Aylmore 1993), or induces $\mathrm{Ca}^{2+}$ deficiency (Dang et al. 1999; Rengasamy et al. 2003). The presence of high salt concentrations in the soil solution (salinity) reduces plant growth, directly affecting physiological functions through increased osmotic potential and specific ion toxicity (Shaw 1997). Subsoils containing a toxic level of $\mathrm{Al}^{3+}$ or deficient amounts of $\mathrm{Ca}^{2+}$ restrict root growth into subsoils (Bruce 1997). At high concentrations, $\mathrm{Cl}^{-}$and $\mathrm{B}^{-}$are toxic to plants, resulting in crop loss (Nuttall et al. 2003; SalCon 1997). Nutrient deficiencies in subsoil could be a major restriction to crops, especially in dryland regions where root growth and functions depend on subsoil water and nutrients (Graham et al. 1992).

The environmental and landscape issues concerning subsoil constraints are related to soil-water relations and aeration resulting from compaction, sodicity, salinity and acidity, and water quality (Fitzpatrick et al. 1995; Rengasamy 2002; SalCon 1997). Subsoil constraints can lead to structural degradation, increased runoff, erosion, waterlogging, water quality problems and loss of natural resources. Such soils can pose a threat to the structural stability in buildings, and bridges, roads and other infrastructures (Fitzpatrick et al. 1995; Naidu and Rengasamy 1993).

\section{Evidences of subsoil constraints in northern region}

Subsoil sodicity

Generally, sodicity is greater in the subsoil, between 0.3 and $1.0 \mathrm{~m}$ soil depth, than in the topsoil. Over $28 \%$ of the total land area of Australia is sodic to a soil depth of $1 \mathrm{~m}$, and it is likely that over $50 \%$ of arable land has sodicity related problems (McKenzie et al. 1993; Shaw et al.1994).

Shaw et al. (1994), using exchangeable sodium percentage (ESP) values at $0.6 \mathrm{~m}$ soil depth of 2009 soil profiles from Queensland, showed that $25 \%$ of soils have

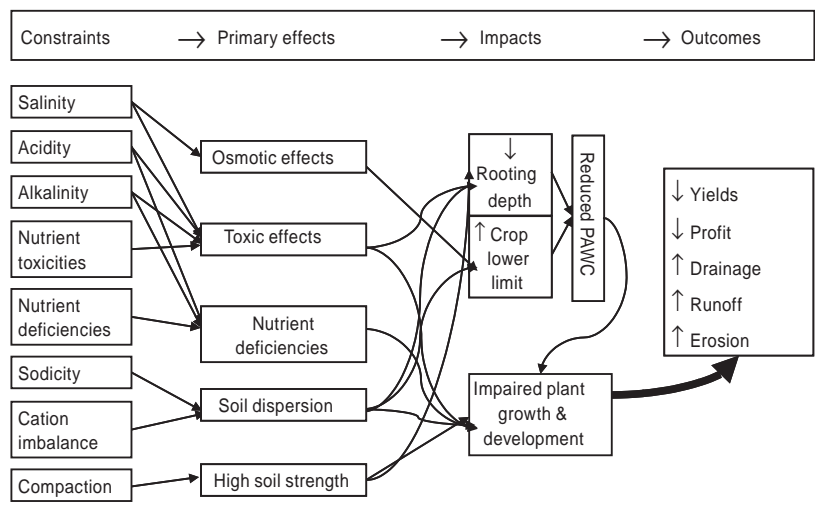

Fig. 1. Impact of subsoil constraints on soil-plant relations, farming, landscape and environment. 
Table 1. Effect of exchangeable sodium percentage (ESP) at $0.6 \mathrm{~m}$ soil depth on plant available water capacity (PAWC) in clay soils in the Central Highlands and Burdekin areas of Queensland and percent loss of PAWC relative to ESP 5\%

\begin{tabular}{lcc}
\hline $\begin{array}{l}\text { ESP at } 0.6 \mathrm{~m} \\
\text { soil depth }(\%)\end{array}$ & $\begin{array}{c}\text { PAWC } \\
(\mathrm{mm})\end{array}$ & $\begin{array}{c}\text { PAWC loss relative to } \\
\text { ESP 5\% }\end{array}$ \\
\hline 5 & 120 & 0 \\
10 & 110 & 8 \\
15 & 100 & 17 \\
20 & 95 & 21 \\
30 & 80 & 33 \\
\hline
\end{tabular}

APAWC loss relative to ESP 5\% was calculated as PAWC $=10 \times(3.57$ $\left.-0.0235 \mathrm{ESP}_{0.6 \mathrm{~m}}\right)^{2}, r^{2}=0.60$ (Shaw 1997).

highly sodic subsoil, with the majority of these occurring in cereal growing areas of the region. Webb et al. (1982) found that all duplex soils studied were strongly sodic at $0.6 \mathrm{~m}$ soil depth, with ESP values greater than 15 .

Within the northern region, sodicity is generally caused by weathering of the parent material, as opposed to current rainfall pattern (McKenzie et al. 1993; Shaw et al. 1994). Sodicity within central Queensland occurs on non-basaltic colluvial, older alluvial and scrub soils (Irvine and Doughton 2001). Vegetation can provide a good indicator of the location of these soils. Dawson Gum (Eucalyptus cambageana), false sandalwood (Eremophila mitchellii) and poplar box (Eucalyptus populnea) are trees commonly found on sodic soils of central Queensland. In most instances, sodicity in southern Queensland increases with increasing soil depth in both red Sodosols as well as Vertosols (Dalal et al. 2002; Dang et al. 2004c; Routley 2003). Daniells et al. (2002) and Schwenke (2002) also showed increased sodicity with soil depth in many cropping soils of northern NSW (Fig. 2). On the Liverpool Plains (NSW), the sodicity level at $0.6 \mathrm{~m}$ soil depth was more than double in plains soils compared with slopes soils (Schwenke 2002).

For dryland crop production in the northern region, water storage in the soil profile is a key factor in determining the potential utilisation of rainfall for plant growth. Limited water entry, water storage (plant available water capacity, PAWC) or root exploitation (rooting depth) restrict the utilisation of water and hence, crop growth. The PAWC is a measure of the size of the soil water storage capacity available for plant growth (Shaw 1997). It is calculated as the difference between the drained upper limit and crop lower limit summed over the rooting depth of the crop (Gardner et al. 1984). Shaw (1997) showed a strong negative relationship between the effect of exchangeable $\mathrm{Na}^{+}$in the middle of root-zone $(0.6 \mathrm{~m})$ on measured PAWC over the rooting depth of the crop for clay soils from the Central Highlands and Burdekin areas of Queensland (Table 1). Although there are many factors affecting soil hydrology, the relationship with ESP alone was sufficiently strong to indicate that increasing levels of $\mathrm{Na}^{+}$reduce water available to plants. This reduced PAWC has direct implications on reduced yield and gross margins (F. Chudleigh, pers. comm.). Furthermore, in recent studies in southern Queensland, Dalal et al. (2002) showed that wheat grain yields strongly decreased from 3.5 to $1.5 \mathrm{t}$ /ha with a decrease in rooting depth from 105 to $45 \mathrm{~cm}$, and was associated with an increase in sodicity from ESP of 4 to 12 in the surface soil (0-0.1 m soil depth) (Table 2).

\section{Subsoil salinity}

In the northern region, subsoil salinity is common in soils dominated by subsoil sodicity. Shaw et al. (1998) found a strong logarithmic relationship between subsoil ESP and electrical conductivity of saturated extract (ECse) except for areas with less than $300 \mathrm{~mm}$ rainfall per year, which have a slightly higher salt concentration. Subsoil salinity in sodic subsoils with low to very low permeability, where ECse increases with ESP, has 2 effects on plant growth: (i) a direct limitation on the available water due to osmotic effect, and (ii) the limited soil wetting and water availability due to high sodicity (Shaw et al. 1998).

By analysing 660 soils from areas within an annual rainfall range of 400-1000 $\mathrm{mm}$ in Queensland, Shaw et al. (1998) found that $78 \%$ of soils with clay contents between 35 and $55 \%$ accumulated salt above ECse of $7.7 \mathrm{dS} / \mathrm{m}$ down to $0.9 \mathrm{~m}$ soil depth. Similar to sodicity, soil salinity is also dependent on the formation of soil. In most instances in central Queensland, salinity occurs at a lower soil depth and generally increases at 0.5 or $0.7 \mathrm{~m}$ soil depth (Irvine and Doughton 2001). However, salinity in most soils of plains in northern NSW increases gradually with soil depth whereas most slopes soils did not show any evidence of high subsoil salinity (Daniells et al. 2002; Schwenke 2002). In southern

Table 2. Rooting depths and wheat grain yields in grey Vertosols of southern Queensland (Dalal et al. 2002)

ESP, exchangeable sodium percentage

\begin{tabular}{lcccc}
\hline Sites & $\begin{array}{c}\text { Rooting } \\
\text { depth }(\mathrm{cm})\end{array}$ & $\begin{array}{c}\text { Wheat yield } \\
(\mathrm{t} / \mathrm{ha})\end{array}$ & $\begin{array}{c}\text { ESP at 0-10 cm } \\
\text { soil depth }(\%)\end{array}$ & $\begin{array}{c}\text { ESP at 60-90 cm } \\
\text { soil depth (\%) }\end{array}$ \\
\hline Goondiwindi, Talwood & 45 & $1.5 \pm 0.3$ & $12 \pm 2$ & $29 \pm 4$ \\
Dulacca, Tara & 75 & $2.5 \pm 0.6$ & $8 \pm 3$ & $27 \pm 4$ \\
Dulacca & 105 & $3.5 \pm 0.5$ & $4 \pm 3$ & $29 \pm 2$ \\
\hline
\end{tabular}


Queensland, subsoil salinity follows a similar pattern to subsoil sodicity (Dang et al. 2004c; Routley 2003) (Fig. 2).

In southern Queensland, Dalal et al. (2002) have shown a significant impact of subsoil salinity on wheat grain yield. With an increase in subsoil salinity at $0.4-0.5 \mathrm{~m}$ soil depth, there was a significant decrease in the wheat grain yields (Fig. 3).
Subsoil acidity and alkalinity

Subsoil acidity in the northern region is common in soils with $\mathrm{N}_{2}$-fixing brigalow (Acacia harpophylla) as the dominant vegetation. In central Queensland, although the $\mathrm{pH}$ of soil often decreases with soil depth, a soil $\mathrm{pH}$ less than 5.5 occurs only at soil depths $0.9 \mathrm{~m}$ or deeper. This decrease in $\mathrm{pH}$ may have little effect on plant growth, due to its depth, but it may
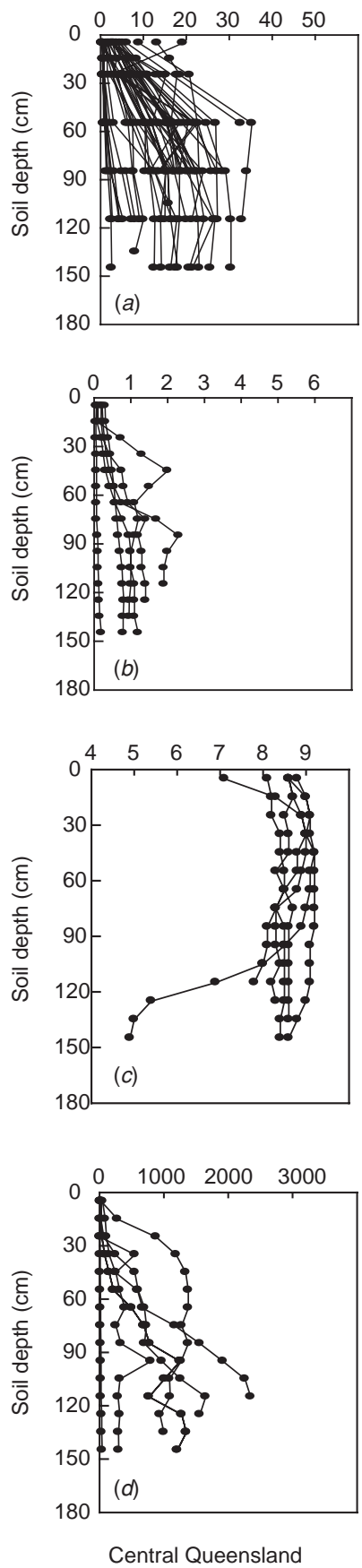
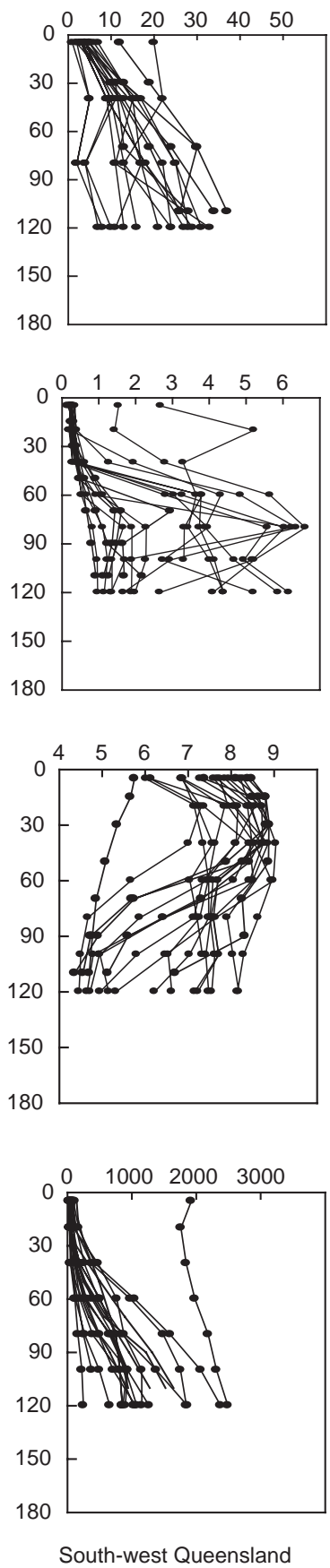
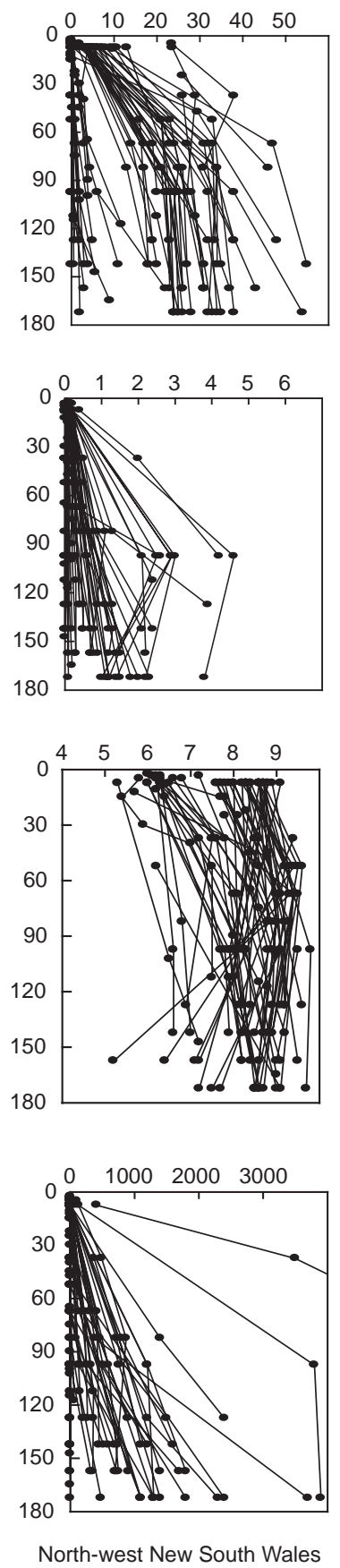

Fig. 2. (a) Exchangeable sodium percentage (ESP), (b) electrical conductivity $\left(\mathrm{EC}_{1: 5}\right),(c)$ soil pH $(1: 5$ soil: water) and $(d)$ chloride $(\mathrm{mg} / \mathrm{kg})$ at various soil depths in some cropping soils with suspected subsoil constraints in central Queensland (Irvine and Doughton 2001), south-west Queensland (Routley 2003) and north-west New South Wales (Daniells et al. 2002; Schwenke 2002). 


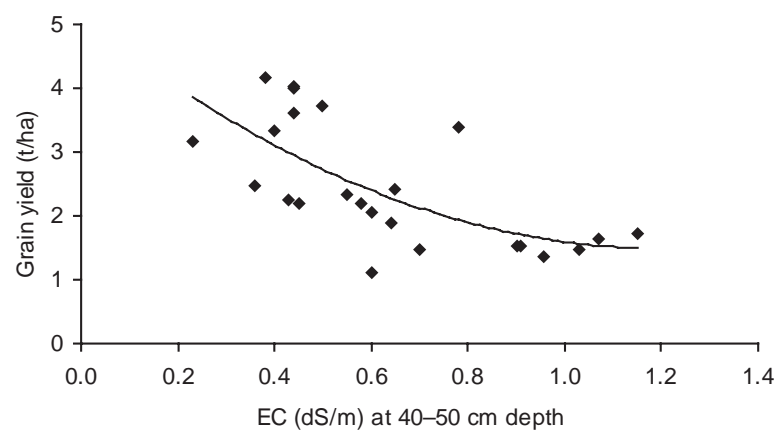

Fig. 3. Relationship between wheat grain yields (t/ha) obtained during 1999 and electrical conductivity (EC 1:5 soil:water) at $40-50 \mathrm{~cm}$ soil depth in grey Vertosols under cereal cultivation in southern Queensland (Dalal et al. 2002). The equation of the line is: $y=1.54 x^{-0.68}, R^{2}=0.49(P<0.01)$.

limit the PAWC of the soil (S. Irvine, pers. comm.). In Vertosols and Sodosols of southern Queensland, the $\mathrm{pH}$ of soil generally increased slightly with soil depths down to $0.4 \mathrm{~m}$, and then decreased thereafter with increasing soil depth. However, the decrease in $\mathrm{pH}$ less than 5.5 generally occurs at soil depths $0.8 \mathrm{~m}$ or deeper (Dang et al. 2004c; Routley 2003). In contrast, the Vertosols of northern NSW generally had an alkaline $\mathrm{pH}$ with a progressive increase in the soil pH with soil depth (Daniells et al. 2002; Schwenke 2002) (Fig. 2).

In alkaline soils, $\mathrm{CO}_{3}{ }^{2-}$ and $\mathrm{HCO}_{3}{ }^{-}$of $\mathrm{Na}$ may be present at high concentrations. Alkalinity can induce either toxicity of $\mathrm{HCO}_{3}^{-}$or induce deficiency of iron (Gupta and Abrol 1990; Naidu and Rengasamy 1993).

\section{Subsoil toxicities}

High concentrations of $\mathrm{Cl}^{-}$have been reported in the soils of the northern region, and they usually increase with soil depth
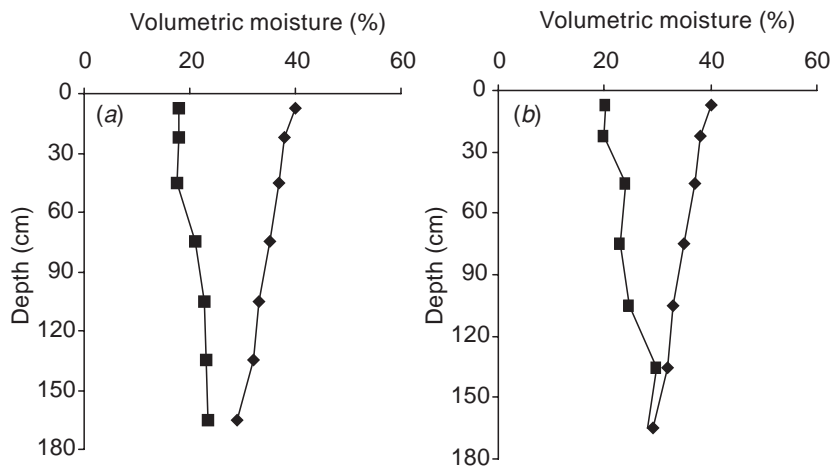

Fig. 4. Plant available water capacity $[\operatorname{PAWC}(\bullet$, drained upper limit, DUL; $\boldsymbol{\square}$, crop lower limit, CLL)] in 2 Kupunn grey Vertosols in adjoining fields at Moonie in southern Queensland with $(a)$ low $\mathrm{Cl}$ $(\mathrm{mg} / \mathrm{kg})$ concentrations $(0-10 \mathrm{~cm}$ soil depth, $36 \mathrm{mg} / \mathrm{kg} ; 30-90 \mathrm{~cm}$, $500 \mathrm{mg} / \mathrm{kg}$; and $90-120 \mathrm{~cm}, 790 \mathrm{mg} / \mathrm{kg}$ ), PAWC-wheat $=237 \mathrm{~mm}$ and (b) high $\mathrm{Cl}(\mathrm{mg} / \mathrm{kg})$ concentrations $(0-10 \mathrm{~cm}$ soil depth, $38 \mathrm{mg} / \mathrm{kg}$; $30-90 \mathrm{~cm}, 605 \mathrm{mg} / \mathrm{kg}$; and $90-120 \mathrm{~cm}, 1230 \mathrm{mg} / \mathrm{kg}$ ), PAWC-wheat = $167 \mathrm{~mm}$ (Dang et al. 2004d).
(Fig. 2). Chloride concentrations as high as $2500 \mathrm{mg} / \mathrm{kg}$ have been reported in soils at $0.9 \mathrm{~m}$ soil depth (Dang et al. 2004c; Routley 2003). The economic impacts of these high $\mathrm{Cl}^{-}$ concentrations in cereals have not been determined; however, evidence for specific yield reductions in relation to $\mathrm{Cl}^{-}$toxicity or osmotic effects is a matter of debate (Bernstein and Hayward 1958). The current evidence strongly suggests that osmotic effects are the primary cause of yield reduction (SalCon 1997). Dalgliesh et al. (2000) and Dang et al. (2004d) reported that in one of 2 similar Kupunn grey Vertosols found in adjoining fields, water was not extracted at soil depths below $1.2 \mathrm{~m}$ and the soil contained high concentrations of $\mathrm{Cl}^{-}(1230 \mathrm{mg} / \mathrm{kg})$ at $0.9-1.2 \mathrm{~m}$ soil depth. The other soil contained $\mathrm{Cl}^{-}$concentrations of $790 \mathrm{mg} / \mathrm{ha}$ at $0.9-1.5 \mathrm{~m}$ soil depth, and water was extracted at soil depths of $1.8 \mathrm{~m}$ (Fig. 4).

Toxicity of boron in the northern region has not been established; however, concentrations of up to $2 \mathrm{mg} \mathrm{B}^{-} / \mathrm{kg}$ in the surface soils and above $10 \mathrm{mg} \mathrm{B}^{-} / \mathrm{kg}$ at $1.0 \mathrm{~m}$ soil depth have been observed (Schwenke 2002).

Aluminium toxicity to plants in low $\mathrm{pH}(<5.5)$ soils is well documented (Bruce 1997). Aluminium toxicity in high $\mathrm{pH}$ conditions due to the predominance of anionic species, aluminate $\mathrm{Al}(\mathrm{OH})_{4}^{-}$, has also been reported (Ma et al. 2003). Aluminate ion concentrations of up to $1.5 \mathrm{mg} / \mathrm{kg}$ have been reported in alkaline subsoils (pH 8.6-9.4) of South Australia (Ma et al. 2003). Although, the information on the presence of $\mathrm{Al}(\mathrm{OH})_{4}{ }^{-}$in soils of northern region is lacking, alkaline subsoils similar to those in South Australia are widespread (Fig. 2).

\section{Subsoil nutrient deficiencies}

Nutrient deficiencies in subsoils may be a major restriction to crop growth, especially in dryland regions where root growth and function depend on subsoil water.
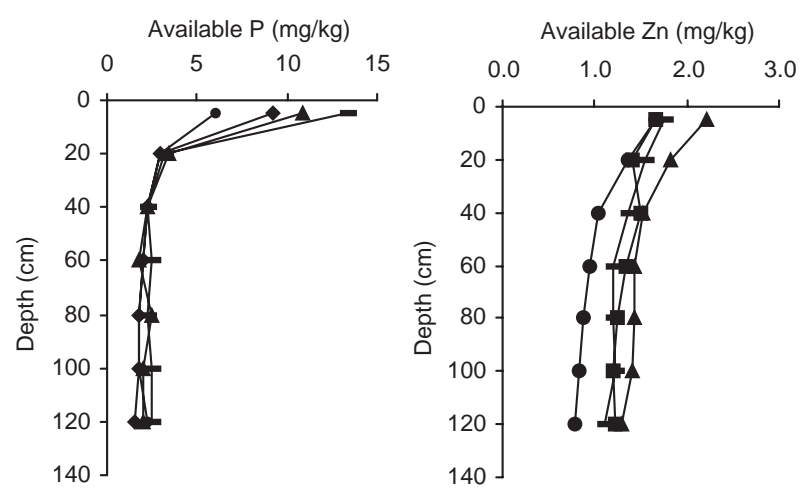

Fig. 5. Profile distributions of (a) bicarbonate extractable-phosphate $(\mathrm{P}, \mathrm{mg} / \mathrm{kg})$ at $\boldsymbol{\bullet}$, site 5 ; $\bullet$, site 6 ; , site 7 ; and $\boldsymbol{\Delta}$, site 8 ; and (b) diethylene triamine penta acetic acid (DTPA)-extractable zinc $(\mathrm{Zn}, \mathrm{mg} / \mathrm{kg}$ ) at $\boldsymbol{\Lambda}$, site 5 ; $\mathbf{\square}$, site 6 ; , site 7 ; and $\boldsymbol{\bullet}$, site 8 according to soil depth $(\mathrm{cm})$ in grey Vertosols under cereal cultivation fertilised with starter-Z applied at $30-40 \mathrm{~kg} / \mathrm{ha}$.annum at Brigalow and Warra in southern Queensland (Dang et al. 2004a). 
Due to high evaporative demand and erratic rainfall in the region, the surface soil is often dry for long periods, thus reducing the diffusion of nutrients and their uptake by the plants, especially phosphorus (P) and zinc ( $\mathrm{Zn})$ (Barber 1984).
In the northern region, less mobile nutrients, such as $\mathrm{P}$ and $\mathrm{Zn}$, have been shown to decrease with soil depth (Dang et al. 2004a) (Fig. 5). Highly mobile ions, such as $\mathrm{NO}_{3}^{-}$, have been shown to concentrate deeper within the soil profile (Thomas et al. 1995; Turpin et al. 1998). A high
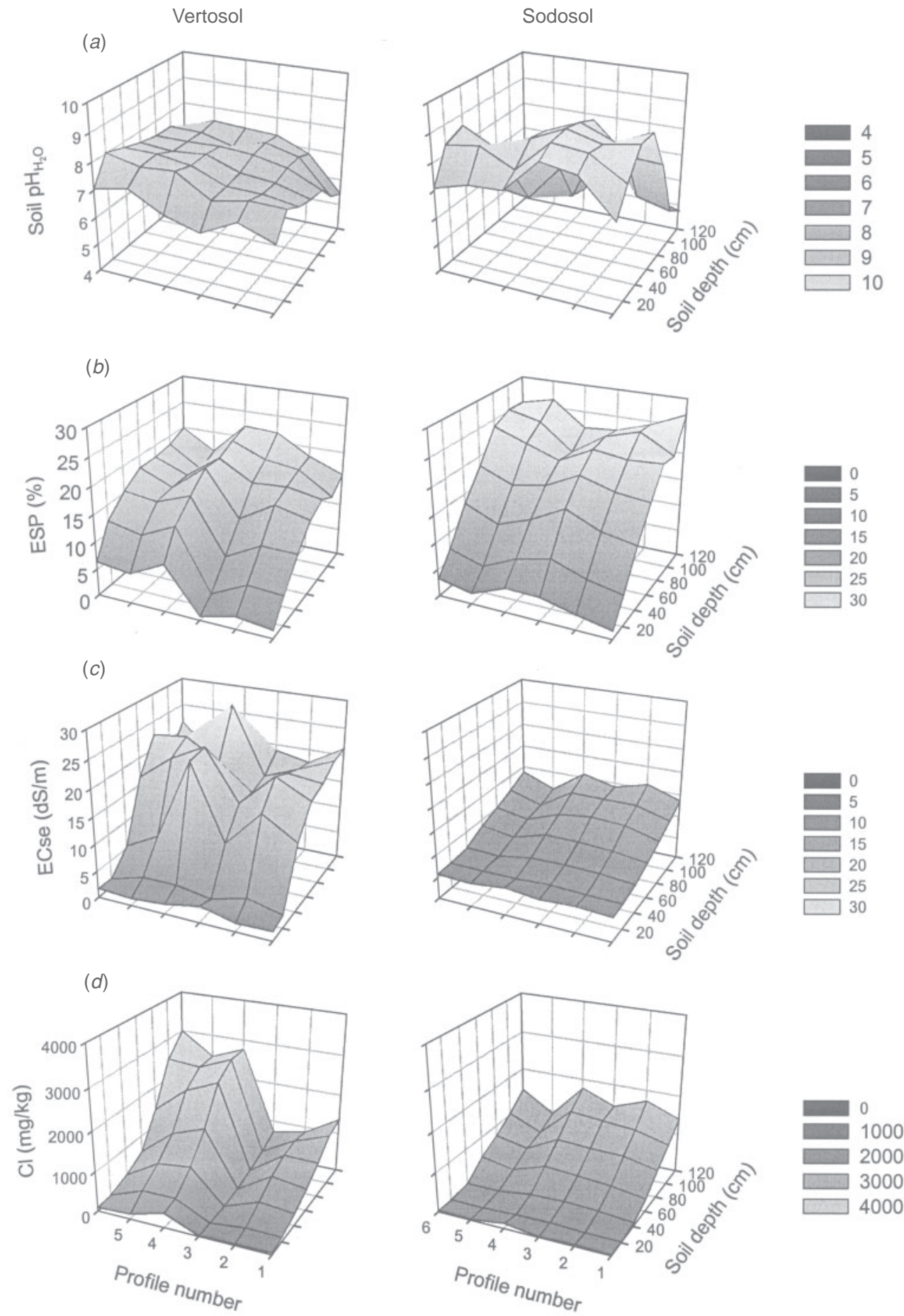

Fig. 6. Variability in $(a)$ soil $\mathrm{pH},(b)$ exchangeable sodium percentage [ESP (\%)], (c) electrical conductivity of saturated extract $[\mathrm{ECse}(\mathrm{dS} / \mathrm{m})]$ and $(d)$ chloride $[\mathrm{Cl}(\mathrm{mg} / \mathrm{kg})]$ at various soil depths at 6 profile points across a paddock containing 2 soil types: Vertosol and Sodosol, in southern Queensland (Dang et al. 2004a). 
concentration of $\mathrm{NH}_{4}^{+}$has also been reported between soil depths of 1.2 and $3 \mathrm{~m}$; however, in some Vertosols, the source of this deposit is unknown (Page et al. 2002).

\section{Physical constraints}

Physical constraints, including compacted soil layers or layers of high bulk density, are widespread in the northern region due to the high clay content with mixed mineralogy and the high plastic limit of these soils. A progressive subsoil compaction is the result of increases in the weight of farm machinery operating on the farm. Considerable evidence exists to show that surface and subsoil compaction exerts an enormous impact on establishment, root penetration, growth and yield of crops, and it persists for a long time (Radford et al. 2000; Radford et al. 2001). Surface compaction can be alleviated by tillage, whereas amelioration of subsurface compaction usually requires natural processes, such as drying and wetting, or biological activity (Pillai and McGarry 1999).

\section{Biological constraints}

Biological constraints in the northern region are related either to an increase in pathogens and nematodes causing soil-borne diseases, or the reduced activities of beneficial microbes, such as vesicular-arbuscular mycorrhizae (VAM) and earthworms. Build-up of pathogenic fungi, nematodes and insect pests has commonly occurred in monoculture cereal cropping (Wildermuth et al. 1997). The most important of these include crown rot, common root rot, root-lesion nematode and yellow spot. In continuous wheat systems, the use of soil conservation practices, such as reduced tillage with stubble retention to reduce soil erosion and conserve soil moisture (Freebairn et al. 1986), favours an increase in the incidence of crown rot (Klein et al. 1988) and soil insect pests (Murray and Wicks 1984) whereas effects on common root rot could be variable depending on $\mathrm{N}$ supply (Wildermuth et al. 1997). The incidence of root-lesion nematodes has increased with wheat monoculture and once a field is infested with these, it is very difficult to eradicate them as they can survive in the subsoil for many years even under clean fallow (Thompson et al. 1994).

A wide variety of physical, chemical and management factors influence the microbial activities in the soils. Farming practices including tillage and periods of fallow have severely depleted earthworms (Robertson 1990), and with extended fallows, VAM also declines (Thompson 1987). Farming practices, including stubble retention, that result in increased organic matter inputs (Dalal and Bridge 1996) favour balanced microbial activities (Gupta 2004; Rengasamy et al. 2003).

\section{Issues in the management of subsoil constraints in dryland farming}

Estimating the severity of subsoil constraints, and their impact on plant productivity and management is a very complex issue. Several soil properties in the subsoils are interacting with each other to determine the exact environment for root growth at a given time. Rarely do the various subsoil constraints occur independently. The various combinations of these may occur in many subsoils of the region. The identification of the most limiting subsoil constraint and its interaction with other factors is a first step.

Soil properties vary spatially and temporally; hence, management of these constraints become site specific. Even within a paddock, large variations in the soil properties occur both horizontally and vertically (Dang et al. 2004a; Nuttall et al. 2001). Dang et al. (2004a) showed large variability in subsoil constraints both within and between the paddocks and in particular ECse, ESP and $\mathrm{Cl}^{-}$concentration than $\mathrm{pH}$ (Fig. 6). For example within a paddock of Vertosol, large variability in $\mathrm{pH}(7.2 \pm 0.5)$, ESP $(5.0 \pm 4.6 \%)$, ECse $(15.6 \pm 7.2 \mathrm{dS} / \mathrm{m})$ and $\mathrm{Cl}(79 \pm 899 \mathrm{mg} / \mathrm{kg})$ were obtained for 6 soil cores taken at $<25 \mathrm{~m}$ apart. Figure 6 showed that
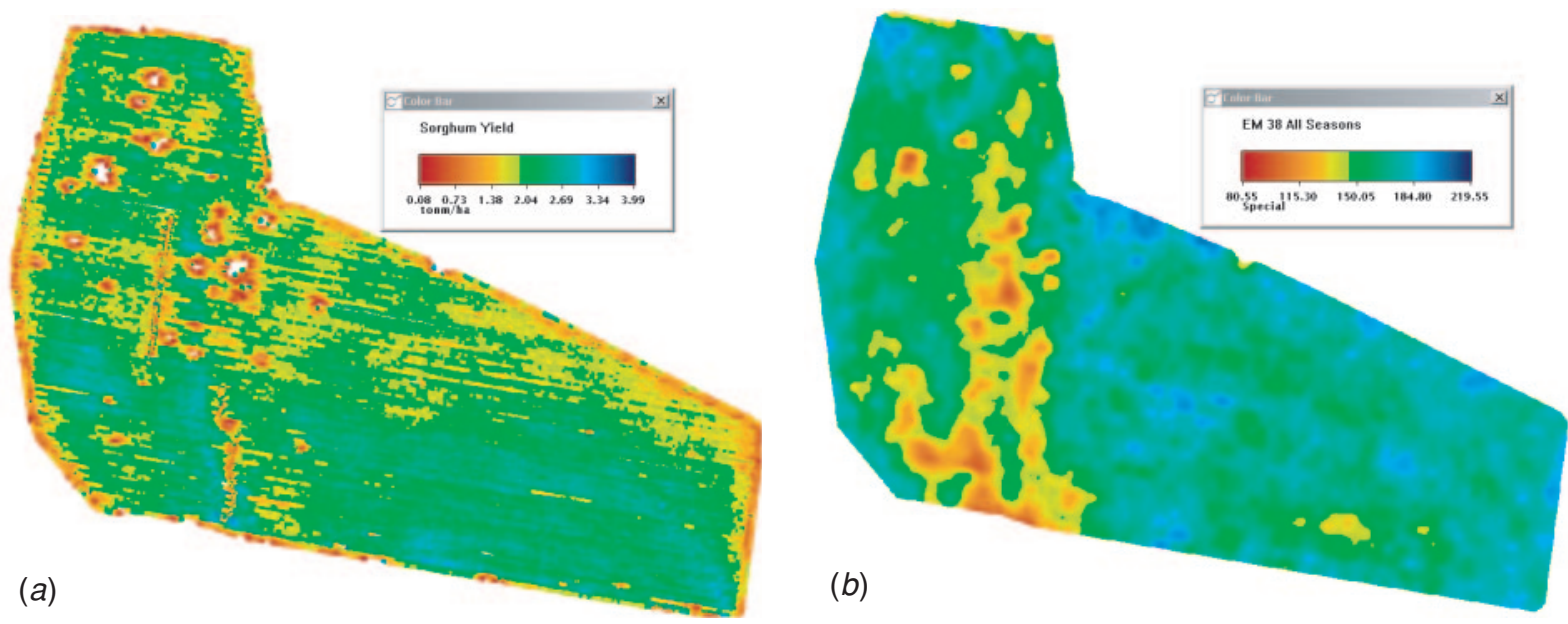

Fig. 7. (a) Sorghum grain yield (t/ha) and (b) EM38 maps of a 136.9 ha paddock containing grey Vertosol at Goondiwindi in southern Queensland showing areas of low and high yield in relation to EM38 measurements (Dang et al. 2004a). 
intra-site variability in subsoil constraints was greater than at inter-site level, which may correspond to marked differences in crop growth and water use. This provides opportunities to manage such variability in subsoil constraints with emerging precision agriculture technologies.

Soil testing for these properties on a large scale would be very expensive. However, a combination of data from existing soil and plant tests, yield maps, EM maps, paddock history and grower's experience can provide the basis for targeted sampling to pinpoint the cause of the problem. Dang et al. (2004a) compared maps of sorghum grain yield with EM38 values (Fig. 7) and obtained a negative linear relationship $\left(R^{2}=0.57, P<0.05\right)$. Soil water, clay contents, ECse, $\mathrm{Cl}^{-}$and ESP determined on soil samples taken at $30 \mathrm{~cm}$ intervals to $1.2 \mathrm{~m}$ soil depths at selected positions, determined from the EM38 map to cover the full range of EM38 measurements, showed linear relationships with average soil profile ECse $\left(R^{2}=0.57, P<0.05\right), \mathrm{Cl}\left(R^{2}=0.58, P<0.05\right)$ and ESP $\left(R^{2}=0.49, P<0.05\right)$. However, the relationship of EM38 readings was non-significant with soil water $\left(R^{2}=0.41\right)$ and clay content $\left(R^{2}=0.42\right)$. Preliminary results suggest that using EM38 maps together with yield maps may offer more realistic economic opportunities to map out large areas of paddock with suspected subsoil constraints. However, significant relationships of EM38 with more than 1 causal factor of subsoil constraints warrants further analysis so as to identify the major limiting factor to root growth, yield and hence, possible options for combating subsoil constraints.

Economic factors largely determine the possible amelioration program for these constraints. A high cost remediation program may not be profitable in dryland farming, as the returns may not be economic, thus making the management options limited.

Depth of soil to be ameliorated would depend on both economic and crop factors. Roots of different crops have varying abilities to penetrate deep in the soil to obtain moisture and nutrients. For example, slower maturing plants like cotton would have $2 \mathrm{~m}$ depths of root-zone whereas short-season plants like mung-bean would have a $1.2 \mathrm{~m}$ depth of root-zone or shallower. Salinity or sodicity at any depth may reduce water and nutrient uptake from that layer (Dalgliesh and Biggs 2003) and hence, would require incorporation of amendments to that depth.

Threshold levels of the causal factors of various constraints in the surface soils have been published in the literature. Briefly, ESP $>6$, EC ( $1: 5$ soil: water $)>0.25 \mathrm{dS} / \mathrm{m}$ (Shaw 1997) and soil pH (water) <5.5 (Bruce 1997) have been considered as threshold levels in the surface soil. However, threshold levels have not been established for subsoils. In northern Australia, the attributes in the subsoil that led to reduced rooting depth and water availability (PAWC) include: EC (1:5 soil: water $)>0.9 \mathrm{dS} / \mathrm{m}$; ESP $>15$ and subsoil $\mathrm{pH}<5.5$ (S. Irvine, pers. comm.). In southern Australia, Nuttall et al. (2003) suggested that subsoil requires an ECse $<8 \mathrm{dS} / \mathrm{m}$ and $\mathrm{ESP}<19$ for crops to make use of water deep in the profile.

\section{Options to manage subsoil constraints}

From the available information, it appears that chemical subsoil constraints owing to sodicity, salinity, $\mathrm{Cl}^{-}$toxicity, nutrient deficiencies and subsoil compaction would have the greatest impact on crop growth in the northern region. Removing or reducing these subsoil constraints could improve crop productivity. Possible options to manage these constraints include amelioration of or managing these constraints to improve the productivity. The amelioration options include (i) chemical (e.g. replacement of $\mathrm{Na}^{+}$and $\mathrm{Mg}^{2+}$ with $\mathrm{Ca}^{2+}$ ); (ii) mechanical (e.g. ripping); or (iii) biological (e.g. use of living plants, green manuring).

The options to manage these constraints include (i) cultural practices (e.g. row spacing, no-till and stubble retention) and (ii) selection of tolerant plants (e.g. selecting crop species and cultivars adapted to subsoil constraints or changing from cropping to pastures or agro-forestry).

There is paucity of information on the management of these constraints in the subsoils. The range of management options discussed here could potentially be tried in the northern region but their effectiveness is unknown.

\section{Mechanical options}

Mechanical means to ameliorate subsoil constraints include chisel plough, sub-soiler or para-plow, which have been used to shatter compacted surface and subsurface soil. The para-plow is particularly suitable but it is expensive to use. Mechanical means to ameliorate compacted layers have met with mixed success (Lal 1995).

Deep ripping or ploughing of clay soils has been shown to increase total porosity, and macroporosity, but these increases were lost within 2 years (Blackwell et al. 1991). Tillage increases water infiltration into the profile but destroys natural soil aggregation, macropores and exposes the surface to erosion (Thomas et al. 1997). Jayawardane and Chan (1994) concluded that the effectiveness of deep ripping in improving subsoil structure depended on the concurrent use of amendments, implement design, soil water content and depth of ripping. Further, in dryland farming, because of lower yield potential, deep tillage is considered uneconomical.

The slotting technique disturbs soil in narrow vertical bands to the required depth to place amendments in high concentration in the slots, thereby preventing rapid loss of macropore stability and improving stabilisation of organic matter (Jayawardane and Blackwell 1986). Although the technique has shown good promise in irrigated conditions, its effectiveness in dryland farms is yet to be proven and its cost is likely to be prohibitive.

\section{Chemical options}

The choice of chemical ameliorant depends on the predominant constraints. The most effective and widely used 
ameliorants for sodic and acidic soils are those providing a soluble source of $\mathrm{Ca}$.

\section{Gypsum}

Gypsum application to ameliorate surface sodicity is a common practice, but it remains unclear how effective the approach will be in rectifying subsoil sodicity. Gypsum application improves sodic surface soils by 2 mechanisms.

(i) An electrolyte effect, which causes flocculation of the surface soil leading to improved infiltration. Given the overburden pressure on subsoils, it is unclear if gypsum will induce flocculation of dispersed sodic subsoil.

(ii) The exchange of $\mathrm{Ca}^{2+}$ for $\mathrm{Na}^{+}$and $\mathrm{Mg}^{2+}$ on the soils exchange complex (Loveday 1976). On highly sodic soils, $\mathrm{Na}^{+}$ions released from the surface layers could increase the sodicity of lower subsoil layers.

For the gypsum to be fully effective in correcting subsoil sodicity, high application rates, sufficient rainfall and time are required. However, in the absence of deep tillage, the effect of surface applied gypsum on subsoil sodicity tends to be slow (Bridge and Kleinig 1968). Sharma (1971) reported that the effect of gypsum extended only to $0.3 \mathrm{~m}$ soil depth after 4 years of application on a red-brown Chromosol in the Riverina, NSW. In the surface soil, gypsum has little residual effect, even with high rates of application on highly sodic soils, suggesting that gypsum may not be a long-term solution to ameliorate surface sodicity. Given that the subsoil will have lower rates of water moving through it when compared with surface soil, gypsum may have a more prolonged residual effect in subsoils, although this remains untested.

The Electrochemical Stability Index $(\mathrm{ESI}=\mathrm{EC}(1: 5$ soil: water)/ESP) can give a guide to the gypsum response; an ESI value less than 0.05 indicates that a soil is likely to flocculate with added electrolyte, such as gypsum (McKenzie et al. 1993). Further, the solubility of gypsum can also be affected by the presence of dominant cations or anions in the soil. For example, $\mathrm{NaCl}$ enhances the solubility of gypsum as compared with $\mathrm{CaCl}_{2}$ or $\mathrm{MgSO}_{4}$, because of the common ion effect where the amount of the less soluble salt in solution decreases (Arslan and Dutt 1993).

Jayawardane and Chan (1994) reviewed several options including deep ripping or deep ploughing to ameliorate sodic subsoils with gypsum. They concluded that amelioration of subsoil sodicity was very expensive, may be uneconomical, and of variable effectiveness, even on similar soils. Also, if sodic subsoils have limited permeability, the $\mathrm{Na}^{+}$on the exchange complex that is replaced by $\mathrm{Ca}^{2+}$ cannot be moved through the profile and hence, reclamation would not occur (Shaw 1997).

\section{Lime}

Lime is used in acid soils mainly to reduce soluble Al, increase the $\mathrm{pH}$ and to supply $\mathrm{Ca}^{2+}$. Lime has been suggested as the most economical ameliorant for surface soil acidity, but surface applied lime is unsuitable for ameliorating acidic subsoils due to its very slow rate of leaching. Deep placement of lime is effective, but difficult and costly. Gypsum has also been successfully used to ameliorate subsoil acidity due to its higher solubility than lime, enabling $\mathrm{Ca}^{2+}$ to move through the soil profile at a greater speed than lime (Shainberg et al. 1989).

Lime and gypsum differ in the way by which they ameliorate acidity. The lime reacts with the acid or protons $\left(\mathrm{H}^{+}\right)$to generate water and carbon dioxide, releasing $\mathrm{Ca}^{2+}$ ions. The acid is consumed in this reaction and increases $\mathrm{pH}$. Gypsum mediates an ameliorative effect not by influencing $\mathrm{pH}$ but by influencing the availability of toxic $\mathrm{Al}$ through increasing the $\mathrm{Ca}: \mathrm{Al}$ ratio in the soil and precipitating some of the active $\mathrm{Al}$ as $\mathrm{Al}_{2}\left(\mathrm{SO}_{4}\right)_{3}$ (Shainberg et al. 1989).

Lime and gypsum differ in solubility: the solubility of lime is $\mathrm{pH}$ dependent, whereas the solubility of gypsum is independent of $\mathrm{pH}$ change. Lime is insoluble at $\mathrm{pH}>8.5$, becoming more soluble as $\mathrm{pH}$ decreases below this value. The use of lime is recommended to ameliorate acid to neutral sodic soils, but is unlikely to have any beneficial effect on alkaline sodic soils.

\section{Gypsum and lime}

Gypsum plus lime amendment has been shown to improve soil structural stability for a longer period of time in soils with near neutral or acidic $\mathrm{pH}$ when compared with gypsum alone. Valzano et al. (2001) suggested that gypsum acts as a useful source of $\mathrm{Ca}^{2+}$ during the early stages after application and its slight acidifying effect improved the dissolution rate of lime to supply $\mathrm{Ca}^{2+}$ for a longer period of time compared with gypsum alone.

\section{Other calcium sources}

Calcium chloride is a very soluble source of $\mathrm{Ca}^{2+}$ and can provide rapid amelioration. However, it is very expensive and may create salinity problems due to its high solubility, and the addition of $\mathrm{Cl}^{-}$may also create $\mathrm{Cl}^{-}$toxicity. Similarly, calcium nitrate can be an effective source of rapid amelioration, but the product is very expensive.

\section{Sulfur}

In alkaline soils ( $\mathrm{pH}>8.5), \mathrm{CO}_{3}{ }^{2-}$ and $\mathrm{HCO}_{3}{ }^{-}$dominate. In these soils, $\mathrm{Ca}^{2+}$ precipitates as calcium carbonate and is not available for exchange with $\mathrm{Na}^{+}$. The most efficient means of reclaiming these soils is to bring their $\mathrm{pH}$ to $<8.5$, so that calcium carbonate dissolves to release $\mathrm{Ca}$. The most common and effective means to acidify these soils is to add sulfuric acid or elemental sulfur, which is converted to sulfuric acid by soil microorganisms. However, large inputs of elemental sulfur to reduce the soil $\mathrm{pH}$ of high clay soils would be required. Therefore, the effectiveness and economics of elemental sulfur addition is yet to be determined for these soils. 


\section{Biological options \\ Roots}

Studies have shown that roots of certain plants alter soil conditions physically, chemically and biologically, and thus, provide benefit to the following crops. Root exudates of legumes generate protons through microbial reactions. These protons can dissolve $\mathrm{CO}_{3}{ }^{2-}$ and $\mathrm{HCO}_{3}{ }^{-}$of $\mathrm{Ca}$ in sodic soils and decrease soil $\mathrm{pH}$, thereby decreasing nutrient availability. Also, by reducing the $\mathrm{pH}$ of the soil, these crops may assist with dissolution of calcium carbonate and the subsequent release of $\mathrm{Ca}^{2+}$ into the soil (Valzano et al. 2001).

Rooting patterns vary between crop species and some species may help in modifying the subsoil environment. Biopores created by roots are more effective than mechanical tillage in opening up the soil, especially the subsoils. The roots of tap-rooted plants, such as lucerne and canola, can drill the soil (through a process known as biological drilling) and create channels after their roots die and decay for the roots of subsequent crop (Elkins 1985).

However, Cresswell and Kirkegaard (1995) found no difference in soil macroporosity under the 2 systems of canola and wheat, and concluded that canola had a limited capability to modify the soil structure. They further hypothesised that dicotyledonous perennials would be more effective than thin fibrous rooted annuals in opening up clayey soils. Peoples (2002) reported that lucerne penetrates deeper into the subsoil and also made macropores wider than phalaris or canola, thereby improving permeability of the subsoil. Yunusa et al. (2002) showed that a 6-year phase of native Acacia created sufficient biopores to significantly improve the structure of a yellow Chromosol compared with annual crop rotation. Growing deep-rooted crops can help in increasing microbial activities in the subsoil as well.

The roots of fibrous-rooted plants can suck the moisture from the soil and help crack the soil through shrinkage and developing cracks. This property is particularly important in cracking clay soils and can possibly provide opportunities to target fertiliser placement and amendments in the subsoil. Pillai and McGarry (1999) showed that growing a crop or pasture could increase the shrink and swell action of a clay soil. They assessed the relative ability of 4 tropical crops to biologically alleviate a compacted Vertosol and found that sorghum and wheat were relatively slow compared with mung bean and lablab in ameliorating compacted subsoil.
Hodgson and Chan (1984) compared the abilities of wheat and safflower to dry and crack a Vertosol to $40 \mathrm{~cm}$ soil depth thus, biologically loosening the subsoil. This resulted in an increase in macroporosity and improved root growth of cotton planted and grown after both the crops, especially after safflower.

\section{Cultural practices}

\section{Zero-tillage and stubble retention}

Tillage management, such as zero-tillage with stubble retention combined with better soil fertility management to ensure optimum production, may provide a long-term solution to arrest or reverse soil sodicity or soil salinity or both. Dalal (1989) showed that stubble retention and no-tillage reduced both ESP and salt levels in a black Vertosol (Table 3). Similar effects of these practices have been observed on a red-brown earth soil (red Chromosol) in southern Queensland (Thomas et al. 1995) and in long-term zero-tillage trials on grey and black Vertosols of northwest NSW (W. Felton, pers. comm.).

Stubble retention and no-tillage help to maintain soil structural stability, and reduced both ESP and salt levels through improved infiltration and increased drainage. Stubble cover would have both chemical and mechanical effects on the soil, increasing organic matter and reducing raindrop impact, thereby assisting in soil stabilisation by decreasing clay dispersion. Further, no-till managed soil produces more biopores due to increased earthworm activity, thereby improving soil structure and movement of water (Valzano et al. 2001).

\section{Deep placement of nutrients}

There are reports showing substantial increases in crop yield when nutrient deficiencies in subsoils are reduced. For example, deep placement of $\mathrm{N}$ and $\mathrm{P}$ in soil for wheat crops, and a combination of nutrients in soil for barley crops, has been shown to significantly increase yields compared with nutrients banded below the seed (Doudle and Wilhelm 2003).

Similarly, adding $\mathrm{Zn}$ to the subsoil has been shown to increase the yield of a $\mathrm{Zn}$-deficient cultivar of wheat by $20 \%$ (Nable and Webb 1991). These yield increases owing to the deep placement of nutrients could be due to root proliferation in the fertilised zones, encouraging greater use of subsoil moisture and greater nutrient uptake (Graham

Table 3. Exchangeable sodium percentage (ESP) and salt concentrations in the Hermitage trial after 13 years of stubble management and tillage in southern Queensland (Dalal 1989)

Means followed by the same letter do not differ significantly $(P<0.05)$

\begin{tabular}{|c|c|c|c|c|c|c|}
\hline \multirow{2}{*}{$\begin{array}{l}\text { Stubble } \\
\text { management }\end{array}$} & \multicolumn{2}{|c|}{ ESP at $0-4 \mathrm{~cm}$ soil depth $(\%)$} & \multicolumn{2}{|c|}{ ESP at $0-10 \mathrm{~cm}$ soil depth (\%) } & \multicolumn{2}{|c|}{ Salt at $0-120 \mathrm{~cm}$ soil depth $(\mathrm{t} / \mathrm{ha})$} \\
\hline & Tillage & Zero-tillage & Tillage & Zero-tillage & Tillage & Zero-tillage \\
\hline Burned & $2.8 \mathrm{a}$ & $2.0 \mathrm{~b}$ & $3.5 \mathrm{a}$ & $3.2 \mathrm{a}$ & $7.3 \mathrm{a}$ & $3.2 \mathrm{bc}$ \\
\hline Retained & $3.1 \mathrm{a}$ & $1.3 \mathrm{c}$ & $3.8 \mathrm{a}$ & $2.2 \mathrm{~b}$ & $4.9 \mathrm{ab}$ & $0.8 \mathrm{c}$ \\
\hline
\end{tabular}


et al. 1992). However, the application of nutrients without correcting physical or chemical constraints, caused by compaction or sodicity, would not improve plant productivity (Blaikie et al. 1989).
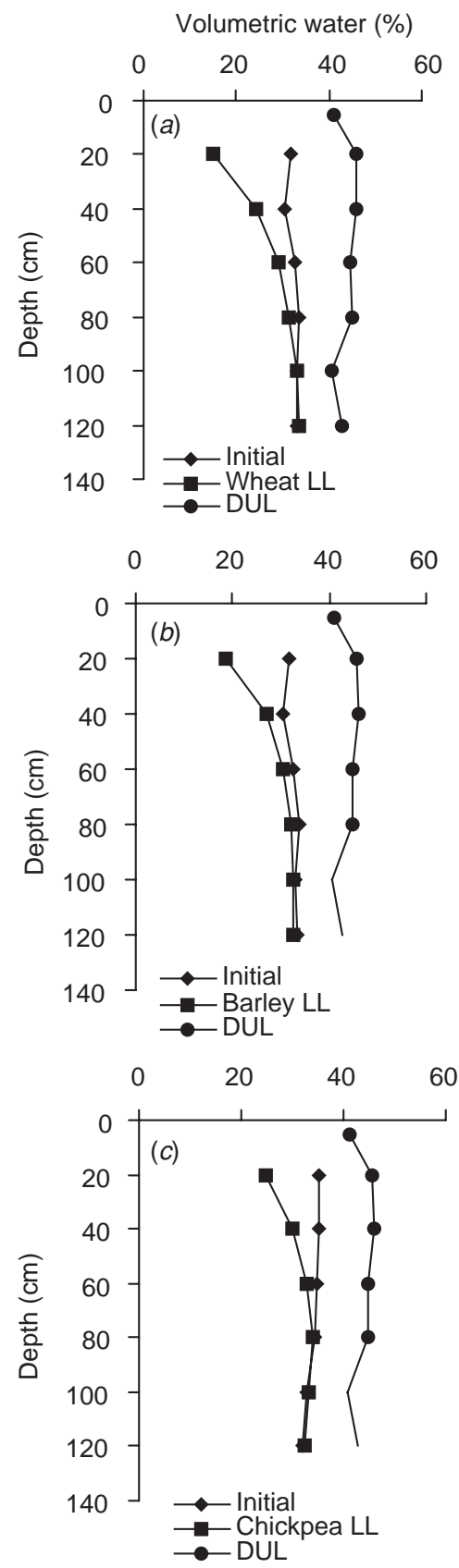

Fig. 8. Water extraction pattern (\%) according to soil depth $(\mathrm{cm})$ in (a) wheat, $(b)$ barley and (c) chickpea crops grown on a saline-sodic Vertosol at Roma in southern Queensland. Values for plant available water capacity [ $(a) 197 \mathrm{a} \mathrm{mm},(b) 182 \mathrm{a} \mathrm{mm}$, and $(c) 154 \mathrm{~b} \mathrm{~mm}]$ in soil profile to rooting depth and crop water use $[(a) 151 \mathrm{a} \mathrm{mm},(b) 141 \mathrm{a} \mathrm{mm}$, and $(c) 127 \mathrm{~b} \mathrm{~mm}$ ], calculated by the addition of the growing season rainfall $(93 \mathrm{~mm})$ and soil water extracted, followed by the same letter do not differ significantly $(P<0.05)$ (Dang et al. 2004c).

\section{Raised beds}

Within raised beds, more favourable root-zone conditions exist for plant growth because there is a greater depth of surface soil, and furrows act as drains, so rapid aeration of the root-zone occurs following rainfall. The soil wets up by subbing (horizontal movement of water from an irrigated furrow to the row bed), so the raised bed layout reduces waterlogging and reduces the incidence of surface crusting, which improves seedbed conditions and crop emergence. However, the use of raised beds in saline soil and regions with shallow watertables can result in salt concentrating on the surface of the beds. The use of raised beds in these areas should be avoided.

Row spacing

In soils with low plant available water, the use of wide row spacing may help to improve total water available to the plants and help improve productivity. Subsoil constraints reduce rooting depth and so plant available water. If row spacing is widened, water and nutrients are metered out, as it takes time for the roots to get into the inter-row area. Therefore, water is still available in crop growth stages when water stress can be critical, such as flowering. However, wider rows may increase problems with weeds.

\section{Plant adaptation}

Crop species

Characterisation and identification of the genetic variability in crops and cultivars adapted to hostile subsoils represents a real challenge but has distinct potential. Considerable variability in sensitivity to hostile subsoils exists among different crops and between cultivars of a crop. For example, durum wheat has a much higher level of salt uptake and much lower level of salt tolerance compared with bread wheat. Durum lacks the $\mathrm{Na}^{+}$exclusion trait (Dvorak et al. 1994; Munns et al. 2000a), which accounts for the better performance of bread wheat than durum wheat on salinesodic soils (Dang et al. 2004c; Rathjen et al. 1999), whereas barley can tolerate high $\mathrm{Na}^{+}$levels compared with both bread and durum wheat (Dang et al. 2004c; Munns et al. 2000b).

Subsoil constraints restrict rooting depth, preventing water uptake by plants. Unused water accumulates in the soil profile, which may result in excessive deep drainage. The selection of crops and cultivars that use more soil water will be challenging. Dang et al. (2004c) showed that cereals, such as wheat and barley, grown on saline-sodic Vertosol were able to extract significantly more water from the soil compared with non-cereals, such as chickpea (Fig. 8). Armstrong et al. (1999) showed that perennials were able to extract more water from the soil than the annual legumes and sorghum. Similarly, Ridley et al. (1997) demonstrated the potential of lucerne grown in rotation with crops to reduce water losses to deep drainage compared with annual crops and pastures. 


\section{Cultivars}

Genetic variability also exists within different cultivars of a crop. Dang et al. (2004b) showed that wheat cv. Baxter extracted significantly more subsoil water than wheat cv. Kennedy grown on a saline-sodic Vertosol, resulting in a slightly higher grain yield of cv. Baxter than cv. Kennedy (Fig. 9). Preliminary results suggest that the low extraction of water by cv. Kennedy than cv. Baxter could partly be due to accumulation of higher $\mathrm{Na}^{+}$and low $\mathrm{K}^{+}$in the young mature leaf blades of cv. Kennedy than cv. Baxter (Dang et al. 2004b).

Varietal differences in tolerance to salts have been reported for other crops including chickpea (Kumar et al. 1983b), Indian mustard (Kumar et al. 1983a), lentils (Maher et al. 2003), rice (Sharma 1986), sorghum (Singh et al. 1990) and sugarcane (Dang et al. 1999).

\section{Pasture}

Changing from cropping to establishing salt-tolerant pasture grass species, fodder shrubs or planting trees can also help manage subsoil constraints. Pasture provides organic matter and fertility to the topsoil. Lucerne in particular can grow through high sodic and saline subsoils, and create big cracks (SalCon 1997). These cracks open up the subsoil for water entry and root penetration by the following cereal crop (Cresswell and Kirkegaard 1995). Forage shrubs, such as saltbush (Atriplex) and related plants, can also tolerate salts.

\section{Agro-forestry}

Many trees, such as Acacia and Eucalyptus spp., have long been used to manage salts and provide other desirable benefits, such as enhancing the farm environment, boosting returns and providing opportunities for diversification into forestry (SalCon 1997). Trees are also a good source of organic matter as they provide leaves, bark and wood. Their
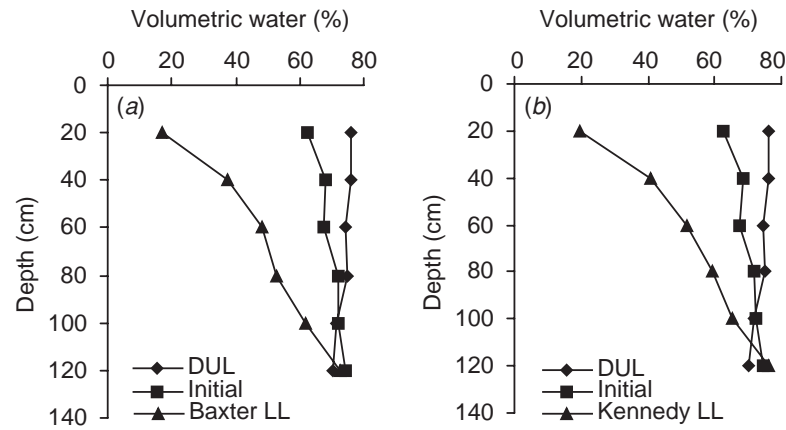

Fig. 9. Water extraction pattern with soil depth $(\mathrm{cm})$ by 2 prime hard wheat cultivars, $(a)$ Baxter and $(b)$ Kennedy, grown on a saline-sodic Vertosol in Goondiwindi in southern Queensland. Values for plant available water capacity [(a) $154 \mathrm{a} \mathrm{mm},(b) 131 \mathrm{~b} \mathrm{~mm}]$ in soil profile to rooting depth, crop water use [ $(a) 255 \mathrm{a} \mathrm{mm},(b) 232 \mathrm{~b} \mathrm{~mm}]$, calculated by the addition of the growing season rainfall $(128 \mathrm{~mm})$ and soil water extracted, and crop yield [(a) 2.12a t/ha, (b) 2.05a t/ha] followed by same letter do not differ significantly at $(P<0.05)$ (Dang et al. 2004b). deep roots help break up large aggregates and provide channels for water entry and drainage.

\section{Summary}

From the available information, it seems that there are limited options currently available to ameliorate subsoil constraints. Optimising crop management practices including stubble retention, no tillage and crop rotations, which include perennial legume crops, pastures and canola or alternative land uses, appear to be viable low-cost techniques to manage subsoil constraints. Characterisation and identification of crops, cultivars and other vegetation adapted to adverse subsoil conditions may provide a long-lasting tangible solution to overcome subsoil constraints.

Richards (2002) concluded that research efforts into root adaptation of hostile subsoil and their use of available water and nutrients should concentrate on (i) an understanding of the specific nature of the subsoil that limits root growth; (ii) how roots of plants colonise hostile subsoil; and (iii) a search for suitable genetic variation for these limiting traits to use in breeding programs.

\section{Gaps in the knowledge of subsoil constraints}

Multiple limitations can exist in the subsoil environment and there is a need to better define these constraints, their interactions with each other and with plant species, soil ameliorants, stubble management and climate. Subsoils are extremely heterogenous and it is often difficult to determine the major limitation to root growth. Large variations in soil properties occur within a paddock, between paddocks and across the landscape. Identification of the variability of soil characteristics throughout the root-zone to construct a subsoil constraints map at the paddock or catchment level would be the starting point for delineating and eventually combating subsoil constraints.

(i) Laboratory analysis for a large number of soil samples from the root-zone at paddock level would be very expensive. On farm, simple, practical and cost effective methods of soil tests will encourage growers to undertake the soil analysis for the entire root-zone.

(ii) The threshold limits of the various subsoil constraints are poorly defined, thus making the interpretation of soil test results difficult. The determination of threshold values for the various subsoil constraints would also provide an opportunity to assess the potential economic loss from subsoil constraints and also to assess the effectiveness of various management solutions.

A range of management options has been suggested for testing. The effectiveness of any management technique, or combination of techniques, will depend on their long-term impact on the soil, the plant, the farming system, the landscape, the environment and the economic issues, such as comparative value of land and cost of implementing various 
management strategy and the landholder's own particular desires and needs. This would require agronomic and chemical assessments in different soil types and agroclimatic regions over several years, taking into consideration climatic variability and sensitivity of crops or cultivars to hostile subsoil conditions.

\section{The Grains Research and Development Corporation Strategic Initiative Project 08 'Combating Sub-soil Constraints'}

Recent work in the northern cropping region has demonstrated that subsoil sodicity and salinity are more widespread than previously thought and in several subregions, presented a major barrier to profitable cropping in most seasons. The Grains Research and Development Corporation (GRDC) reviewed its investment strategy for 2002-03 for potential research development and extension into improving farming outcomes from landscapes with sodic and saline subsoils. The rationale behind this initiative was to determine the extent and location of subsoil constraints to farming in the northern region and to develop strategies to manage or manage around these constraints. After scoping this initiative, a project has commenced targeting subsoils that constrain grain yield in the cracking clay cropping lands of the northern NSW and Queensland. It will provide insight into improved knowledge and management of these constraints.

The research focus is to improve the knowledge and ability of farmers and advisors to identify and manage subsoil constraints, which would lead to an increase in productivity as well as economic and environmental sustainability. The 3 expected outcomes of the project are (i) to obtain information and knowledge on the extent, distribution and impact under varying seasonal conditions; (ii) to identify improved farming systems and agronomic practices for the management of subsoil constraints that are cost effective and environmentally sustainable; and (iii) to develop practical methods and action learning tools to enable growers to identify and manage subsoil constraints. The other most important aspect of the initiative is to utilise the experience of growers, and the expertise of public and private advisors through on-farm participatory research and extension activities. This will increase the awareness of these constraints in farming communities and help to combat these constraints at the paddock level.

This study is supported by the grain growers and the Federal Government through GRDC and involves the Queensland Departments of Natural Resources and Mines, the Queensland Department of Primary Industries and Fisheries, the NSW Department of Primary Industries, the NSW Department of Infrastructure Planning and Natural Resources, CSIRO, and the Universities of Western Sydney and Queensland.

\section{Conclusions}

Considering the variability and possible interactions between causal factors of subsoil constraints, it is likely that no single agronomic practice or farming system technology would provide a solution to the multiple complex problems of subsoil constraints. However, a combination of management options might help manage or work around these constraints. It is likely that identification of crops, which can tolerate these hostile subsoils, could be the most promising option. Exploitation of genetic variability within a crop species could provide a long-term solution to the problem of subsoil constraints. Profitable and sustainable crop production on soils with subsoil constraints will require working with growers to obtain a sound understanding of the subsoil constraints, agronomic management and breeding opportunities. Also, alternative land uses, such as permanent pastures or long-term pastures and agro-forestry, need consideration. All of these management options will be vital to maximise resource use and improve productivity.

\section{Acknowledgments}

We thank Grains Research and Development Corporation in Australia for funding the project (GRDC-SIP08: DNR0004), Ms Mirella Blasi for unpublished data (GRDC-DNR7), and Dr Greg Thomas, Dr Andrew Biggs and Dr Greg Chapman and 2 reviewers for comments and valuable suggestions.

\section{References}

Ahern CR, Isbell RF, Weinand MMG (1993) Acid surface soil distribution and extent in Queensland, Australia. In 'Proceedings of the 3rd international symposium on plant-soil interactions at low pH: principles and management'. pp. 147-153. (Kluwer Academic Publisher: Dordrecht, Netherlands)

Armstrong RD, McCosker K, Johnson SB, Walsh KB, Millar G, et al. (1999) Legume and opportunity cropping systems in central Queensland. I. Legume growth, nitrogen fixation and water use. Australian Journal of Agricultural Research 50, 909-924. doi:10.1071/AR98100

Arslan A, Dutt GR (1993) Solubility of gypsum and its prediction in aqueous solutions of mixed electrolytes. Soil Science 155, 37-47.

Barber SA (1984) Zinc. In 'Soil nutrient bioavailability'. pp. 346-363. (Wiley-Interscience Publication: New York)

Bell M (2004) Subsoil secrets starts to come out. In 'Grains Research and Development Corporation research update'. Available at http://www.grdc.com.au/whats_on/mr/north/northern_region04014 .htm (verified 3 January 2006)

Bernstein L, Hayward HE (1958) Physiology of salt tolerance. Annual Review of Plant Physiology 9, 25-46. doi:10.1146/annurev.pp. 09.060158 .000325

Blackwell PS, Jayawardane NS, Green TW, Wood JT, Blackwell J, et al. (1991) Subsoil macropore space of a transitional red-brown earth after either deep tillage, gypsum or both. I. Physical effects and short-term changes. Australian Journal of Soil Research 29, 123-140. doi:10.1071/SR9910123

Blaikie SJ, Kelly KB, Mason WK (1989) Effects of ameliorating exposed subsoil prior to sowing on water relations and productivity of pasture during an irrigation cycle. Australian Journal of Agricultural Research 40, 97-106. doi:10.1071/AR9890097 
Bolan NS, Hedley MJ, White RE (1991) Processes of soil acidification during nitrogen cycling with emphasis on legume based pastures. Plant and Soil 134, 53-63.

Bridge BJ, Kleinig CR (1968) The effect of gypsum on the water storage in a sandy loam soil under an irrigated perennial pasture. In 'Transactions 9th international congress on soil science. Vol. 1'. pp. 313-323. (CSIRO Soils: Adelaide)

Bruce RC (1997) Soil acidification. In 'Sustainable crop production in the sub-tropics'. (Eds AL Clarke, PB Wylie) pp. 97-111. (Queensland Department of Primary Industries: Brisbane)

Cassidy NG (1971) Effect of irrigation water on heavy clay soils at Dalby. Agricultural Chemistry Laboratory Branch, Queensland Department of Primary Industries, Technical report No. 2.

Cresswell HP, Kirkegaard JA (1995) Subsoil amelioration by plant roots-the process and the evidence. Australian Journal of Soil Research 33, 221-239. doi:10.1071/SR9950221

Dalal RC (1986) Cultivation effects on salinity and sodicity of Brigalow soils in southern Queensland. In 'Landscape soil and water salinity. Brisbane conference and workshop series publication QC86001'. pp. 1-5. (Queensland Department of Primary Industries: Brisbane)

Dalal RC (1989) Long-term effects of no-tillage, crop residue, and nitrogen application on properties of a Vertisol. Soil Science Society of America Journal 53, 1511-1515.

Dalal RC, Bridge BJ (1996) Aggregation and organic carbon storage in sub-humid and semi-arid soils. In 'Advances in soil science. Structure and organic matter storage in agricultural soils'. (Eds MR Carter, BA Stewart) pp. 263-307. (CRC Press Inc.: New York)

Dalal RC, Strong WM, Weston EJ, Copper JE, Lehane KJ, et al. (1995) Sustaining productivity of a Vertisol at Warra, Queensland, with fertilisers, no-tillage, or legumes I. Organic matter status. Australian Journal of Experimental Agriculture 35, 903-913. doi:10.1071/ EA9950903

Dalal RC, Blasi M, So HB (2002) High sodium levels in subsoil limits yields and water use in marginal cropping areas. Grains Research and Development Corporation Project No. DNR 6, final report, Canberra.

Dalgliesh NP, Biggs A (2003) Effective rooting depth: getting to know your soil. In 'National farm groups manual-GRIST, Northern region'. pp. 15-16. (Greenmount press: Toowoomba, Qld)

Dalgliesh NP, Foale M (1998) 'Soil matters: monitoring soil water and nutrients in dryland farming.' (Agricultural production systems research unit: Toowoomba, Qld)

Dalgliesh NP, Hochman Z, Hargreaves D (2000) Using soil resource information to explore production issues with farmers. In 'Proceedings for Soil 2000: New horizons for a new century. Australian and New Zealand second joint soils conference. Vol. 2'. (Eds JA Adams, AK Metherall) pp. 77-78. (New Zealand Society of Soil Science, Lincoln University: Christchurch, New Zealand)

Dang YP, Mehla AS, Chhabra R, Kumar S (1999) Sodicity induced yield losses and changes in mineral concentration of sugarcane genotypes. International Society of Sugar Cane Technologists XXIII Congress 23, 89-97.

Dang Y, Dalal R, Harms B, Routley R, Kelly R, McDonald M (2004a) Subsoils constraints in the grain cropping soils of Queensland. In 'Supersoil conference, national soils conference, Sydney, 6-9 December 2004'. (Ed. B Singh) Available at http://www.grdc.com.au/growers/res_upd/north/04/dang.htm (verified 3 January 2006)

Dang Y, Richard R, McDonald M, Dalal R, Buck S (2004b) Insight into the management of hostile subsoils. In 'Grains Research \& Development Corporation research update'. pp. 14-19. Available at http://www.grdc.com.au/growers/res_upd/north/04/dang.htm (verified 3 January 2006)
Dang Y, Routley R, McDonald M, Dalal R, Alsemgeest V, et al. (2004c) Effects of chemical subsoil constraints on lower limit of plant available water for crops grown in southwest Queensland. In 'Proceedings for the 4th international crop science congress, Brisbane, Australia'. (Eds T Fischer, N Turner, J Angus, L McIntyre, M Robertson, A Borrell) Available at http://www.regional.org.au/ au/cs/2004/poster/1/3/1/1209_dangy.htm (verified 3 January 2006)

Dang Y, Routley R, McDonald M, Dalgliesh N, Dalal R (2004d) Subsoils - how do they vary and what is their impact on the plant available water for different crops and management. Grain Research and Development Corporation research update, Westmar. pp. 13-17. (ICAN Hornsby: NSW Australia) Available at http://www.grdc.com.au/growers/res_upd/north/n04/dang2.htm (verified 3 January 2006)

Daniells I, Manning B, Pearce L (2002) 'Profile descriptions: district guidelines for managing soils in north west NSW.' (The Centre for Crop Improvement: Tamworth, NSW)

Doudle S, Wilhelm N (2003) Subsoil nutrition on Eyre Peninsula. In 'National farm groups manual-GRIST, Southern region'. pp. 29-32. (Greenmount press: Toowoomba, Qld)

Dvorak J, Noaman MM, Goyal S, Gorham J (1994) Enhancement of the salt tolerance of Triticum turgidum L. by the Kna 1 locus transferred from the Triticum aestivum L chromosome 4D by homeoelogous recombination. Theoretical and Applied Genetics 87, 872-877.

Elkins CB (1985) Plant roots as tillage tools. In 'Proceedings international conference on soil dynamics. Vol III.' pp. 519-523. (International conference on soil dynamics conference: Auburn, AL)

Fitzpatrick RW, Boucher SC, Naidu R, Fritsch E (1995) Environmental consequences of soil sodicity. In 'Australian sodic soils: distribution, properties and management'. (Eds R Naidu, ME Sumner, P Rengasamy) pp. 163-176. (CSIRO Soils: Adelaide)

Freebairn DM, Ward LD, Clarke AL, Smith GD (1986) Research and development of reduced tillage systems for Vertisols in Queensland, Australia. Soil and Tillage Research 8, 211-229. doi:10.1016/01671987(86)90335-1

Gardner EA, Shaw RJ, Smith GD, Coughlan KJ (1984) Plant available water capacity: concept, measurement and prediction. In 'The properties and utilization of cracking clay soils'. (Eds JW McGarity, EH Hoult, HB So) pp. 164-175. (University of New England: Armidale, NSW)

Graham RD, Turner NC, Ascher JS (1992) Evidence of subsoil constraints and potential benefits from amelioration. In 'Proceedings of the national workshop on subsoil constraints to root growth and high soil water and nutrient use by plants'. pp. 1-10. (CSIRO Soils: Adelaide )

Gupta V (2004) Intensive cropping starts with the soil. In 'Grains research \& development corporation research update'. Available at http://www.grdc.com.au/growers/gc/gc48/news4.htm (verified 3 January 2006)

Gupta RK, Abrol IP (1990) Salt affected soils: their reclamation and management for crop production. Advances in Soil Science 11, 224-288.

Helyar KR, Porter WM (1989) Soil acidification, its measurement and the processes involved. In 'Soil acidity and plant growth'. (Ed. AD Robson) pp. 365-382. (Academic Press Australia: Sydney)

Hodgson AS, Chan KY (1984) Deep moisture extraction and crack formation by wheat and safflower in a Vertisol following irrigated cotton rotations. In 'The properties and utilization of cracking clay soils'. (Eds JW McGarity, EH Hoult, HB So) pp. 299-304. (University of New England: Armidale, NSW)

Hossain SA, Dalal RC, Waring SA, Strong WM, Weston EJ (1996) Comparison of legume-based cropping systems at Warra, Queensland. I. Soil nitrogen and organic carbon accretion and potentially mineralisable nitrogen. Australian Journal of Soil Research 34, 273-287. doi:10.1071/SR9960273 
Irvine SA, Doughton JA (2001) Salinity and sodicity, implications for farmers in Central Queensland. In 'Proceedings of the 10th Australian agronomy conference'. (The Australian Society of Agronomy Inc.: Hobart) Available at http://www.regional.org.au/ $\mathrm{au} / \mathrm{asa} / 2001 / 3 / \mathrm{b} /$ irvine.htm (verified 3 January 2006)

Jayawardane NS, Blackwell J (1986) Effect of gypsum enriched slotting on infiltration rates and moisture storage in a swelling clay soil. Soil Use and Management 2, 114-118.

Jayawardane NS, Chan KY (1994) The management of soil physical properties limiting crop production in Australian sodic soils-a review. Australian Journal of Soil Research 32, 13-44. doi:10.1071/ SR9940013

Klein TA, Summerall BA, Burgess LW (1988) Influence of stubble management practices on crown rot of wheat. Plant Protection Quarterly 3, 10-11.

Knowles TA, Singh B (2003) Carbon storage in cotton soils of northern New South Wales. Australian Journal of Soil Research 41, 889-903. doi:10.1071/SR02023

Kumar D, Singh MP, Buttar BS (1983a) Effect of sodicity on Indian mustard cultivars. Current Agriculture 7, 145-149.

Kumar D, Singh MP, Buttar BS (1983b) Effect of sodicity on emergence, establishment and growth of chickpea. International Chickpea Newsletter 8, 15-17.

Lal R (1995) Minimum tillage systems. In 'Advances in Soil Science. Subsoil management techniques'. (Eds NS Jayawardane, BA Stewart) pp. 1-34. (CRC Press Inc.: New York)

Leaney FWJ, Herczeg AL (1999) The origin of fresh groundwater in the SW Murray basin and its potential for salinisation. CSIRO Land and Water, Technical report No. 7/99, Adelaide.

Loveday J (1976) Relative significance of electrolyte and cation exchange effects when gypsum is applied to a sodic clay soil. Australian Journal of Soil Research 14, 361-371. doi:10.1071/ SR9760361

Ma G, Rengasamy P, Rathjen AJ (2003) Phytotoxicity of aluminium to wheat plants in high-pH solutions. Australian Journal of Experimental Agriculture 43, 497-501. doi:10.1071/EA01153

Maher L, Armstrong R, Connor D (2003) Salt tolerant lentils — a possibility for the future? In 'Proceedings of the 11th Australian agronomy conference'. (The Australian Society of Agronomy Inc.: Geelong, Vic.) Available at http://www.regional.org.au/au/asa/ 2003/c/17/maher.htm\#TopOfPage(verified 3 January 2006)

McGarry D (1992) Degradation of soil structure. In 'Land degradation processes in Australia'. (Eds G McTainsh, W Boughton) pp. 71-305. (Longman Cheshire: Melbourne)

McKenzie DC, Abott TS, Chan KY, Slavich PG, Hall DJM (1993) The nature, distribution and management of sodic soils in New South Wales. Australian Journal of Soil Research 31, 839-868. doi:10.1071/SR9930839

Muller P (1999) Cropping soils of central Queensland. In 'Crop management notes, central Queensland'. pp. 10-13. (Queensland Department of Natural Resources and Mines DNRQ 97109)

Munns R, Hare RA, James RA, Rebetzke GJ (2000a) Genetic variation for improving the salt tolerance of durum wheat. Australian Journal of Agricultural Research 51, 69-74. doi:10.1071/AR99057

Munns R, Hare RA, Colmer TD (2000b) Salt tolerance in wheat and barley. In 'Proceedings of the 8th international barley genetics symposium. Vol. I'. (Ed. S Logue), pp. 238-245. (University of Adelaide: Adelaide)

Murray DAH, Wicks R (1984) Baiting for soil dwelling insects. In 'Proceedings of the 4th Australian entomological research conference'. (Eds P Bailey, D Swincer) pp. 268-273. (SA Government printer: Adelaide)
Nable RO, Webb MJ (1991) Response of two wheat genotypes to low subsoil zinc supply. In 'Proceedings of the 4th international symposium on genetic aspects of mineral nutrition'. pp. 66-68. (Kluwar Academic Publisher: Dordrecht, Netherlands)

Nable RO, Banuelos GS, Paull JG (1997) Boron toxicity. In 'Boron in soils and plants: reviews'. (Eds B Dell, PH Brown, RW Bell) pp. 181-198. (Kluwer Academic Publishers: Dordrecht, Netherlands)

Naidu R, Rengasamy P (1993) Ion interactions and constraints to plant nutrition in Australia. Australian Journal of Soil Research 31, 801-819. doi:10.1071/SR9930801

Nuttall JG, Armstrong RD, Connor DJ (2001) Understanding subsoil water-use by cereals on southern Mallee soils: I. Spatial characteristics of subsoil constraints. In 'Proceedings of the 10th Australian agronomy conference'. (Australian Society of Agronomy Inc.: Hobart) Available at http://www.regional.org.au/ au/asa/2001/1/a/nuttall1.htm (verified 3 January 2006)

Nuttall JG, Armstrong RD, Connor DJ (2003) Evaluating physiochemical constraints of Calcarosols on wheat yield in the Victorian southern Mallee. Australian Journal of Agricultural Research 54, 487-497. doi:10.1071/AR02168

Page KL, Dalal RC, Menzies NW, Strong WM (2002) Nitrification in a Vertisol subsoil and its relationship to the accumulation of ammonium-nitrogen at depth. Australian Journal of Soil Research 40, 727-735. doi: $10.1071 /$ SR01087

Peoples M (2002) Using primer plants to produce passages. In 'Grains Research and Development Corporation research update'. Available at http://www.grdc.com.au/growers/cd/south/Southern_ Region1051.htm (verified 3 January 2006)

Pillai UP, McGarry D (1999) Structure repair of a compacted Vertisol with wet/dry cycles and crops. Soil Science Society of America Journal 63, 201-210.

Radford BJ, Bridge BJ, Davis RJ, McGarry D, Pillai UP, Rickman JF, et al. (2000) Changes in soil properties of a Vertisol and responses of wheat after compaction with harvester traffic. Soil and Tillage Research 54, 155-170. doi:10.1016/S0167-1987(00)00091-X

Radford BJ, Yule DF, McGarry D, Playford C (2001) Crop responses to applied soil compaction and to compaction repair treatments. Soil and Tillage Research 61, 157-166. doi:10.1016/S0167-1987(01) 00194-5

Rathjen AJ, Brand JD, Liu CY, Paull JG, Cooper D (1999) Breeding for tolerance to soil toxicities. In 'Proceeding of the 11th Australian plant breeding conference'. (Eds P Langridge, A Barr, G Auricht, G Collins, A Granger, D Handford, J Paull) pp. 34-38. (University of Adelaide: Adelaide)

Rengasamy P (2002) Transient salinity and subsoil constraints to dryland farming in Australian sodic soils: an overview. Australian Journal of Experimental Agriculture 42, 351-361. doi:10.1071/ EA01111

Rengasamy P, Chittleborough D, Helyer K (2003) Root-zone constraints and plant based solutions for dryland salinity. Plant and Soil 257, 249-260. doi:10.1023/A:1027326424022

Richards RA (2002) Current and emerging environmental challenges in Australian agriculture-the role of plant breeding. Australian Journal of Agricultural Research 53, 881-892. doi:10.1071/AR02052

Ridley AM, White RE, Simpson RJ, Callinan L (1997) Water use and drainage under phalaris, cocksfoot, and annual ryegrass pastures. Australian Journal of Agricultural Research 48, 1011-1023. doi:10.1071/A96157

Robertson LN (1990) Interactions between agriculture and animals in north Queensland. In 'Agriculture and the ecosystems in north Queensland'. (Eds KL Norman, AL Garside) pp. 56-64. (Australian Institute of Agricultural Science: Hawthorn, Vic.) 
Routley R (2003) Subsoil constraints in the Maranoa-soil survey and crop monitoring results from 2002. In 'Grains research and development corporation research update'. Available at http://www.grdc.com.au/growers/res_upd/north/03/maranoa.htm (verified 3 January 2006)

SalCon (1997) Salinity management handbook. (Queensland Department of Natural Resources and Mines: Indooroopilly, Qld.)

Schwenke G (2002) Soil nutrient survey - the current status in black soils on the Liverpool Plains. In 'Grains research and development corporation research update'. Available at http://www.grdc.com.au/ growers/res_upd/north/02/quirindi_soil_survey.htm (verified 3 January 2006)

Shainberg I, Sumner ME, Miller WP, Farina MPW, Pavan MA, et al. (1989) Use of gypsum on soils: a review. Advances in Soil Science 9, 1-11.

Sharma ML (1971) Physical and physio-chemical changes in the profile of a sodic soil treated with gypsum. Australian Journal of Soil Research 9, 73-82. doi:10.1071/SR9710073

Sharma SK (1986) Mechanism of tolerance in rice varieties differing in sodicity tolerance. Plant and Soil 93, 141-145.

Shaw RJ (1997) Salinity and sodicity. In 'Sustainable crop production in the sub-tropics'. (Eds AL Clarke, PB Wylie). pp. 79-96. (Queensland Department of Primary Industries, QI 97035: Brisbane)

Shaw RJ, Brebber L, Ahern CR, Weinand MMG (1994) A review of sodicity and sodic soil behaviour in Queensland. Australian Journal of Soil Research 32, 143-172. doi:10.1071/SR9940143

Shaw RJ, Coughlan KJ, Bell LC (1998) Root zone sodicity. In 'Sodic soils: distribution, properties, management and environmental consequences'. (Eds ME Sumner, R Naidu) pp. 95-106. (Oxford University Press: New York)

Sinclair SE, Clarke MR, Kelly AM (1996) Waste minimisation in the Australian feedlot industry: a perspective with regard to salinity parameters observed in commercial feedlots. Animal Production in Australia 21, 278-281.

Singh KN, Sharma DK, Chillar RK (1990) Effect of soil sodicity on the yield, chemical composition and uptake of nutrients by jowar (Sorghum bicolor) cultivars. Annals of Agricultural Research 11, 233-240.

So HB, Aylmore LAG (1993) How do sodic soils behave? The effects of sodicity on soil physical behaviour. Australian Journal of Soil Research 31, 761-779. doi:10.1071/SR9930761

Thomas GA, Gibson G, Nielsen RGH, Martin WD, Radford BJ (1995) Effects of tillage, stubble, gypsum, and nitrogen fertiliser on cereal cropping on a red-brown earth in south-west Queensland. Australian Journal of Experimental Agriculture 35, 997-1008. doi:10.1071/EA9950997
Thomas GA, Felton WL, Radford BJ (1997) Tillage and crop residue management. In 'Sustainable crop production in the sub-tropics'. (Eds AL Clarke, PB Wylie) pp. 195-213. (Queensland Department of Primary Industries, QI 97035: Brisbane)

Thompson JP (1987) Decline of vesicular-arbuscular mycorrhizae in long-fallow disorder of field crops and its expression in $\mathrm{P}$ deficiency of sunflower. Australian Journal of Agricultural Research 38, 847-867. doi:10.1071/AR9870847

Thompson JP, Brennan PS, Clewett TG, O'Reilly MM (1994) Tolerance and resistance to Pratylenchus thornei. In 'Proceedings of the 7th assembly of the wheat breeding society of Australia, Adelaide'. pp. 213-216. (The University of Adelaide: Adelaide)

Turpin JE, Thompson JP, Waring SA, MacKenzie J (1998) Nitrate and chloride leaching in Vertosols for different tillage and stubble practices in fallow-grain cropping. Australian Journal of Soil Research 36, 31-44. doi:10.1071/S97037

Valzano FP, Greene RSB, Murphy BW, Rengasamy P, Jarwal SD (2001) Effects of gypsum and stubble retention on chemical and physical properties of a sodic grey Vertosol in western Victoria. Australian Journal of Soil Research 39, 1333-1347. doi:10.1071/SR00045

Webb AA, Dowling AJ, Nugent PJ (1982) Studies on solodic soils under Acacia harpophylla-Eucalyptus cambageana forest in central Queensland. I. Chemical characteristics. Queensland Journal of Agricultural and Animal Sciences 39, 109-123.

Webb AA, Grundy MJ, Powell B, Littleboy M (1997) The Australian sub-tropical cereal belt: soils, climate and agriculture. In 'Sustainable crop production in the sub-tropics'. (Eds AL Clarke, PB Wylie) pp. 8-26. (Queensland Department of Primary Industries, QI 97035: Brisbane)

Wildermuth GB, Thompson JP, Robertson LN (1997) Biological changes: diseases, insects and beneficial organisms. In 'Sustainable crop production in the sub-tropics'. (Eds AL Clarke, PB Wylie) pp. 112-130. (Queensland Department of Primary Industries, QI 97035: Brisbane)

Yunusa IAM, Mele PM, Rab MA, Schefe CR, Beverly CR (2002) Priming of soil structural and hydrological properties by native woody species, annual crops, and a permanent pasture. Australian Journal of Soil Research 40, 207-219. doi:10.1071/SR01038

Received 26 April 2004, accepted 14 January 2005 